\title{
Detection of coccolithophore blooms in ocean color satellite imagery: A generalized approach for use with multiple sensors
}

\author{
Timothy S. Moore ${ }^{\mathrm{a}, *}$, Mark D. Dowell ${ }^{\mathrm{b}}$, Bryan A. Franz ${ }^{\mathrm{c}}$ \\ a Ocean Process Analysis Laboratory, Morse Hall, University of New Hampshire, Durham, NH 03824, USA \\ ${ }^{\mathrm{b}}$ Institute for Environment and Sustainability, European Commission, JRC, Via E. Fermi, 2749 I-21027 Ispra (VA), Italy \\ c Ocean Biology Processing Group, NASA/Goddard Space Flight Center, Greenbelt, Maryland 20771, USA
}

\section{A R T I C L E I N F O}

\section{Article history:}

Received 16 May 2011

Received in revised form 23 August 2011

Accepted 2 October 2011

Available online 10 November 2011

\section{Keywords:}

Ocean color

Classification

Coccolithophores

Optical water types

\begin{abstract}
A B S T R A C T
A generalized coccolithophore bloom classifier has been developed for use with ocean color imagery. The bloom classifier was developed using extracted satellite reflectance data from SeaWiFS images screened by the default bloom detection mask. In the current application, we extend the optical water type (OWT) classification scheme by adding a new coccolithophore bloom class formed from these extracted reflectances. Based on an in situ coccolithophore data set from the North Atlantic, the detection levels with the new scheme were between 1,500 and 1,800 coccolithophore cells/mL and 43,000 and 78,000 liths/mL. The detected bloom area using the OWT method was an average of 1.75 times greater than the default bloom detector based on a collection of SeaWiFS $1 \mathrm{~km}$ imagery. The versatility of the scheme is shown with SeaWiFS, MODIS Aqua, CZCS and MERIS imagery at the $1 \mathrm{~km}$ scale. The OWT scheme was applied to the daily global SeaWiFS imagery mission data set (years 1997-2010). Based on our results, average annual coccolithophore bloom area was more than two times greater in the southern hemisphere compared to the northern hemisphere with values of $2.00 \times 10^{6} \mathrm{~km}^{2}$ and $0.75 \times 10^{6} \mathrm{~km}^{2}$, respectively. The new algorithm detects larger bloom areas in the Southern Ocean compared to the default algorithm, and our revised global annual average of $2.75 \times 10^{6} \mathrm{~km}^{2}$ is dominated by contributions from the Southern Ocean.
\end{abstract}

(c) 2011 Elsevier Inc. All rights reserved.

\section{Introduction}

Coccolithophores are a group of phytoplankton that inhabit a wide variety of marine environments and are distinctive by their production of small calcium plates or coccoliths which are organized around each living cell as an outer covering. These organisms synthetically produce each coccolith plate from calcium carbonate, and have a significant role in the calcium and carbonate cycling in the oceans. At certain times under favorable conditions, coccolithophore blooms can occur on extremely large spatial scales. These blooms can be visible in ocean color satellite imagery as a result of light scattering by the coccolith plates detached from cells - released through cell death and coccolith overproduction - suspended in near-surface waters. The characteristic optical signature of a 'visible' coccolithophore bloom is a very bright patch of water with a turquoise color.

Coccolithophore blooms in the global oceans have been observed for many years, pre-dating ocean satellite imagery (Tyrrell \& Merico, 2004). Their geologic distributions have been mapped from oceanic sediment analysis, and have covered significant portions of the earth's oceans. However, it was in the satellite era that the pattern

\footnotetext{
* Corresponding author. Tel.: +1 603863 690; fax: +1 6038620243.

E-mail addresses: timothy.moore@unh.edu (T.S. Moore),

mark.dowell@jrc.ec.europa.eu (M.D. Dowell), bryan.a.franz@nasa.gov (B.A. Franz).
}

distributions and frequencies of blooms as large-scale phenomena were systematically observed and quantified. These large, visible blooms are almost always composed of the species Emiliania huxleyi (Tyrrell \& Merico, 2004). It is one of the most ubiquitous of all phytoplankton species, having an extremely high temperature and salinity tolerance, and has been shown to grow from low to high light and in a wide range of nutrient conditions. When E. huxleyi bloom, cells produce excess coccoliths which are shed into the water column, and also release coccoliths upon cell death which generally number around 15-30 per cell (Paasche, 2002). The cell and lith concentrations to achieve this condition are somewhat debatable, but a nominal value of 1,000 cells $/ \mathrm{mL}$ has been suggested (Tyrrell \& Merico, 2004; Tyrrell \& Taylor, 1996). These bloom events are usually found at mid to high latitudes in both hemispheres. Due to their important role in affecting the biogeochemistry of the water column and feedbacks to climate, detecting and monitoring these types of bloom events are increasingly important to fully understand the connections between climate and phytoplankton ecological processes.

A bloom classifier was developed by Brown and Yoder (1994) for use with CZCS imagery to detect the spatial pattern of coccolithophore blooms based on characteristics of the upwelled spectral light field. The algorithm was later adapted to SeaWiFS imagery by Iglesias-Rodriguez et al. (2002). The classifier is based on a parallelepiped algorithm which classifies a satellite pixel as either 'bloom' or 
'non-bloom' based on the comparison of the pixel's spectral upwelled light properties to a set of conditional statements that define a shape and magnitude range for which a bloom qualifies. This algorithm is also currently used for MODIS ocean color imagery, where the $531 \mathrm{~nm}$ channel is substituted for the $510 \mathrm{~nm}$ channel. Since there is not a one-to-one translation between these two wavelengths, the parallelepiped algorithm is not as effective with MODIS, and blooms are not efficiently detected in MODIS imagery. Other ocean color algorithms developed to target coccolithophores that take advantage of their unique optical properties include the particulate inorganic carbon (PIC) algorithm (Balch et al., 2005), a coccolithophore bloom algorithm based on anomaly detection (Shutler et al., 2010), and an optical model based on inherent optical properties of coccoliths (Smyth et al., 2002).

Spectral reflectance characteristics have also been used as the basis for a more general global classification scheme that identifies optical water types (OWTs) in ocean color images (Moore et al., 2009). In this scheme, eight OWTs were identified from a global in situ data base of reflectance spectra obtained from the NOMAD data set (Werdell and Bailey, 2005), and ranged from clear blue-water types to turbid, coastal water types (Fig. 1). These eight OWTs were statistically characterized and served as the basis for a membership function, which can be applied to ocean color imagery to produce OWT membership maps. These maps portray the degree of membership to a given OWT, represented by a number between zero and one with higher values indicating a closer relation between the pixel's reflectance spectra and that of the given OWT. The maps generally show coherent membership patterns that fade into one another to varying degrees, and collectively encompass a visual picture similar to that of a jigsaw puzzle with each OWT membership map being a puzzle piece.

The OWTs are representations of different optical conditions ranging from clear, oligotrophic water (OWT 1) to turbid, sedimentdominated water (OWT 8). The eight types numerically follow this optical progression. From a general perspective, the organization of the OWTs can be viewed as subdivisions of the classic case 1 /case 2 water types originally suggested by Morel and Prieur (1977), with OWTs 1-4 representing case 1 waters and OWTs 5-8 representing case 2 waters. They are analogous to land coverage types and functionally serve as end members from a mathematical point of view, but the OWTs are not specified as natural bio-optical end members from a geophysical point of view.

Together, the OWTs encompass a wide range of optical conditions found in the oceans. However, the current OWT classification scheme does not account for coccolithophore blooms. The evidence for a missing coccolithophore bloom water type can be seen in

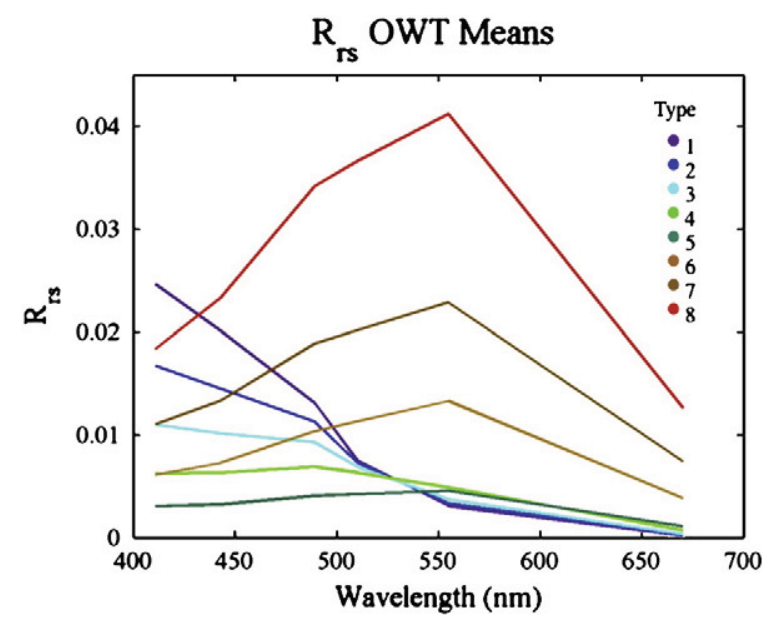

Fig. 1. The eight OWT remote sensing reflectance $\left(R_{r S}\right)$ mean spectra derived from the NOMAD data set. All $R_{r s}$ are sub-surface $(0-)$. membership maps from images with known coccolithophore blooms. It is apparent from examining the upwelled reflectance at $555 \mathrm{~nm}$ from an image with a known coccolithophore bloom and the accompanying map of the sum of the memberships to all eight OWTs that the area of low membership sum is exactly patterned after the bloom region (Fig. 2). These patterns appear in other images with coccolithophore blooms, and thus provide the motivation to include an optical water type specifically associated with coccolithophore blooms in the context of the OWT classification scheme.

This research aims to fill in this gap by creating a new water type in the scheme that is distinct for coccolithophore blooms. The expansion of the OWT scheme to include a coccolithophore type would fill in the missing gap, and also provide a mechanism to identify coccolithophore blooms across ocean color platforms, as the OWT scheme is applicable to multiple ocean color satellites. We will show that the new coccolithophore OWT can be built from a reflectance database constructed from different SeaWiFS images with known coccolithophore blooms by using the existing bloom classifier to screen the appropriate pixels. This new OWT will essentially re-cast the existing SeaWiFS bloom classifier into the OWT framework, which will free the constraint from particular wavelengths. This will also provide continuity between the two classification schemes.

The objectives of this research were:

1) to develop a method that extends and is consistent with the coccolithophore bloom algorithm for SeaWiFS, CZCS, MERIS and MODIS ocean color satellite imagery; 2) to integrate the coccolithophore reflectance characteristics into the larger framework of the existing OWT classification method that is independent of satellite platform, and 3) to evaluate the global area of coccolithophore blooms over the mission of the SeaWiFS sensor.

\section{Methods}

\subsection{Creating a coccolithophore reflectance database}

The overall approach is centered on the statistical characterization of the reflectance distribution of coccolithophore blooms as the basis for a new optical water type to be added to the existing OWT scheme. The current lack of in situ reflectance measurements for blooms precluded the use of any in situ data for this characterization. Instead, we chose to base the optical characterization on reflectance data extracted from satellite images that contained coccolithophore blooms. The database of spectral reflectances was specifically formed from a collection of $1 \mathrm{~km}$ SeaWiFS level 2 images (standard NASA processing) using the existing SeaWiFS coccolithophore bloom mask as the pixel selection criteria. Thus, the bloom definition used here is dependent on the criteria set by the existing coccolithophore bloom detection algorithm (Brown \& Yoder, 1994). The image set included 14 separate images from six different regions and spanned six years worth of coverage (Table 1 ).

The light field quantity used in the OWT scheme is the sub-surface remote sensing reflectance $-R_{r s}(0-)$. This specific optical form is used in the calculations of memberships to the OWTs. $R_{r s}(0-)$ can be defined as the ratio of the upwelled spectral radiance $\left(L_{u}(0-)\right)$ to the downwelled spectral irradiance $\left(E_{d}(0-)\right)$ just below the sea surface and is related to the above-water reflectance $R_{r s}(0+)$ by (Lee et al., 2002):

$R_{r s}(0-)=L_{u}(0-) / E_{d}(0-)=R_{r s}(0+) /\left(0.52+1.7 * R_{r s}(0+)\right)$

where the spectral subscripts have been supressed. All pixels extracted from the SeaWiFS satellite imagery were converted from $R_{r s}(0+)$ to $R_{r s}(0-)$. Subsequent references to the term reflectance are related to $R_{r s}(0-)$ unless otherwise noted. 

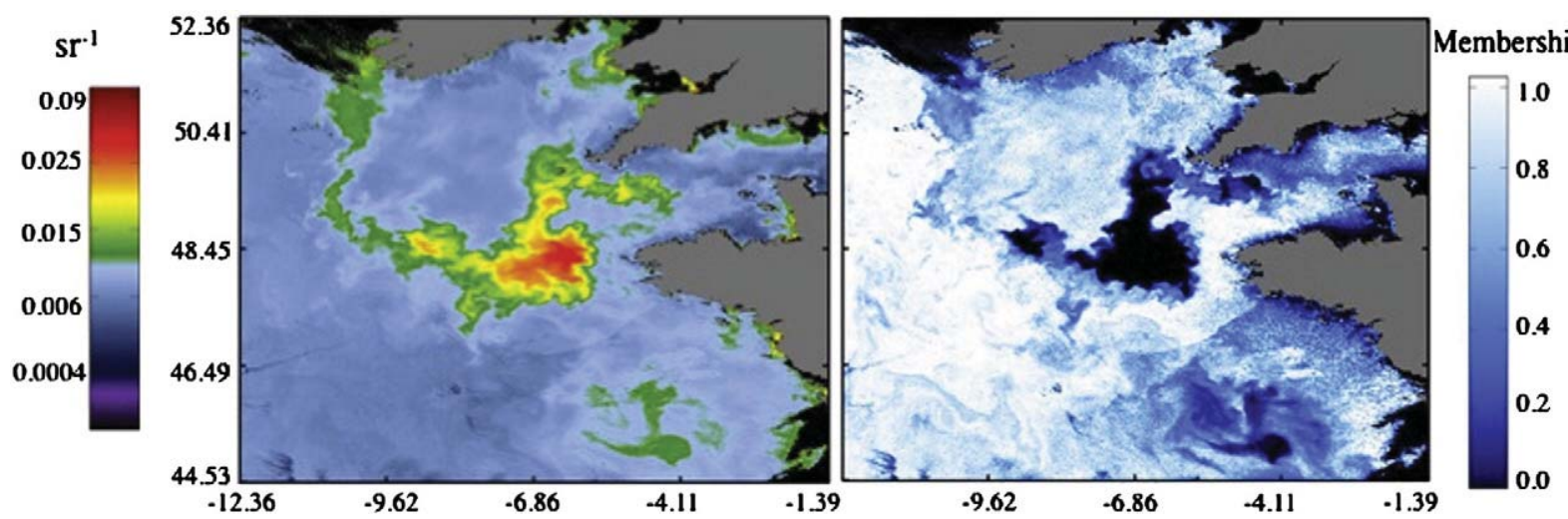

Fig. 2. Left: remote sensing reflectance at $555 \mathrm{~nm}$ for a SeaWiFS image from June 15, 2004 off the coast of France with an offshore coccolithophore bloom. Right: the sum of fuzzy memberships to the eight OWTs from the same image. The low membership areas in the offshore areas (black region) coincide with the location of the coccolithophore bloom.

The total number of coccolithophore bloom pixels totaled roughly 600,000 extracted sets of observations at six wavelengths (412, 443, $490,510,555$, and $670 \mathrm{~nm})$, and were tabulated into a single matrix. This matrix served as the data source for casting the reflectance properties of coccolithophore blooms into the OWT framework. The statisticals required from this data matrix were the mean and covariance matrix of the remote sensing reflectance, which are the two factors that govern the fuzzy membership function. Once defined, these statistics were added to the existing matrix of the eight OWTs derived from NOMAD. We will describe the membership function below, but we first address the characterization of the coccolithophore reflectance data set.

\subsection{The spectral reflectance characterization of coccolithophore blooms}

Although the range of the coccolithophore reflectance spectral shapes in the training data set is constrained by the SeaWiFS bloom detection algorithm, there is still a wide degree of variability within the boundaries set by the parallelepiped algorithm. While the most significant aspect of this variability is in the magnitudes of the reflectance spectra, there were also different spectral shapes that were evident. Therefore, the cluster analysis protocol applied to the NOMAD data set (Moore et al., 2009) was applied to this training data set to find the inherent class structure. The result of this analysis created and identified a family of spectral curves that represented different coccolithophore bloom spectra from the satellite data set.

Table 1

The SeaWiFS $1 \mathrm{~km}$ level 2 images used to form the coccolithophore reflectance database. All images were obtained from the NASA OBPG MLAC version 6 collection.

\begin{tabular}{|c|c|c|c|}
\hline \multicolumn{4}{|c|}{ SeaWiFS image collection } \\
\hline Image number & Image ID & Location & $\begin{array}{l}\text { Coccolith mask } \\
\text { pixels }\end{array}$ \\
\hline 1 & S1998115235805.L2_MLAC & Bering Sea & 108443 \\
\hline 2 & S1998166123254.L2_MLAC & North Sea & 164298 \\
\hline 3 & S1999202155327.L2_MLAC & Nova Scotia & 25410 \\
\hline 4 & S2000120232121.L2_MLAC & Bering Sea & 64736 \\
\hline 5 & S2000131131445.L2_MLAC & Celtic Sea & 12868 \\
\hline 6 & S2000178124819.L2_MLAC & Celtic Sea & 9153 \\
\hline 7 & $S 2001186121400 . L 2_{-} M L A C$ & North Sea & 11536 \\
\hline 8 & S2001316142943.L2_MLAC & Patagonian Shelf & 34275 \\
\hline 9 & S2001317151214.L2_MLAC & Patagonian Shelf & 39648 \\
\hline 10 & S2001331151401.L2_MLAC & Patagonian Shelf & 62526 \\
\hline 11 & S2003184164318.L2_MLAC & Nova Scotia & 3758 \\
\hline 12 & S2004137141000.L2_MLAC & Bay of Biscay & 20831 \\
\hline 13 & S2004167133614.L2_MLAC & Celtic Sea & 19231 \\
\hline 14 & S2004173142323.L2_MLAC & Iceland & 44665 \\
\hline
\end{tabular}

To review this process, the fuzzy c-means clustering algorithm (Bezdek, 1981) was applied to the reflectance spectra and cluster centers were identified. The important decision of choosing the correct number of the clusters was obtained by sequentially changing the number of clusters (an input variable) for each independent cluster run, and then applying a set of cluster validity functions (Pal \& Bezdek, 1995) to the output which assess performance metrics of the cluster outcome. The optimal number of clusters is chosen based on the validity function indicators. For a detailed description of the validity functions applied, see Moore et al. $(2009,2001)$ and references therein.

Since the training data set was large and cluster algorithms are inherently sensitive to the size of the input array, the training set was randomly subsampled to create a smaller data set of 2,500 points which was comparable to NOMAD. A total of 25 independent iterations were run. The final reflectance characterization was based on one of these runs that was representative of the most frequent outcome of the 25 random subsampled data sets. From a statistical viewpoint, there were negligible differences among the runs.

The formation of a new optical water type in the context of the global reflectance classes is the collective result of the new clusters found in the coccolithophore data set. The original number of OWTs was eight, and this has now been augmented to nine, but the ninth OWT is represented by the ensemble of the coccolithophore bloom reflectance types (i.e., cluster means). Although these new types are characterized separately from a statistical point of view, collectively they formed the single coccolithophore OWT by summing the memberships to these classes.

\subsection{The membership function for the optical water types}

In the OWT scheme, each OWT is functionally equivalent to a class in the context of data clustering or pattern recognition, where a class can be viewed as a source of patterns whose distributions in feature space is governed by a probability density specific to the class (Jain et al., 1999). Thus, the membership of a given observation to a class can be described by using this definition as a rule, and this membership can be expressed in terms of a fuzzy value. That is, membership can be expressed not in the classical sense of belonging to either this class or that class exclusively, but with looser constraints to allow for an observation to have partial membership to any class (Zadeh, 1965). This also implies that an observation can have membership to multiple classes. For this, a membership function which can accommodate intermediate values is required and can be defined as a fuzzy membership function.

The fuzzy membership function described in Moore et al. (2009) is a two-step process. The first step is the calculation of the Mahalanobis distance between an observed reflectance and a class mean 
reflectance vector. In this case, the computation is a distance between points in multi-dimensional reflectance space with each spectral channel being a dimension. In formal terms, the proximity of a given input reflectance vector to a mean OWT reflectance vector is described by the Mahalanobis distance (Rencher, 1995):

$Z^{2}=\left(\vec{R}_{r s}-\vec{\mu}_{j}\right)^{t} \Sigma_{j}^{-1}\left(\vec{R}_{r s}-\vec{\mu}_{j}\right)$

where $\vec{R}_{r s}$ is the remote sensing reflectance vector, $\vec{\mu}_{j}$ is the mean reflectance vector and $\Sigma_{j}^{-1}$ is the covariance matrix for the $j$ th OWT. The Mahalanobis distance is a weighted form of the Euclidean distance and is advantageous because it incorporates the structure and shape of the distribution of points around the cluster center.

In the second step, the Mahalanobis distance is converted to a continuous membership using a chi-square probability function. In mathematical terms, if the probability distribution of points belonging to the class centered at $\vec{\mu}_{j}$ is normal and $\vec{R}_{r s}$ is a member of that population, then $Z^{2}$ as defined by Eq. (2) has a chi-squared distribution with $n$ degrees of freedom where $n$ is the dimensionality of $\vec{R}_{r s}$. The likelihood that $\vec{R}_{r s}$ is drawn from the jth class can be defined as:

$f_{j}=1-F_{n}\left(Z^{2}\right)$

where $F_{n}\left(Z^{2}\right)$ is the cumulative chi-square distribution function with $n$ degrees of freedom. The membership ranges from zero to one and depicts the degree to which a measured reflectance vector belongs to a given OWT. It has a value of one if the measured vector is identical to the mean vector of that OWT, and its value diminishes to zero as the Mahalanobis distance increases. This provides a mathematical way to represent the degree of association of a reflectance observation to each OWT. For any given a pixel or in situ observation with a reflectance vector, independent memberships are derived to each OWT.

These fuzzy memberships can be transformed into a crisp or hard membership by selecting the OWT with the highest fuzzy membership. When a satellite pixel is assigned to the OWT with the highest fuzzy membership, the dominant OWT of the pixel is being expressed. This expression is a convenient way to represent the dominant OWTs from all image pixels onto a single map. The dominant OWT maps derived for satellite images also serve as masks for the given optical condition. Thus, a coccolithophore bloom mask can be obtained by selecting pixels that are assigned to OWT 9 as the dominant type. These masks will later be used in the global analysis.

\subsection{Satellite and in situ data sets}

Fuzzy and dominant memberships were computed for two different in situ data sets to the new OWT configuration - the NOMAD data set and an in situ data set from the North Atlantic that contained two different coccolithophore blooms. Since all original NOMAD data points were assigned to OWTs $1-8$, this data set was re-analyzed with the new scheme to check for any mis-classification as a result of the added OWT 9. The North Atlantic data set (Smyth et al., 2002) contained 14 stations that were inside and outside bloom patches. Measurements included spectral radiometry, coccolithophore counts and lith counts. These stations were tested using the in situ spectral reflectances and extracted reflectances from SeaWiFS matchup imagery. These data were also tested for bloom qualification using the SeaWiFS standard coccolithophore algorithm.

A collection of ocean color satellite images were processed with the new OWT configuration. Same-day image pairs for select $1 \mathrm{~km}$ level 2 SeaWiFS and MODIS Aqua were processed and the resulting membership maps were compared for consistency. Image classification was also applied to select CZCS and MERIS level 2 scenes that contained coccolithophore blooms. A time series of level 3 SeaWiFS
$9 \mathrm{~km}$ global daily data from 1997 to 2010 was classified, and 8-day average global membership maps were produced for each OWT. Standard level 3 binning of SeaWiFS data screen out certain pixels from level 2 to level 3 processing, and this includes the coccolithophore mask using the standard coccolithophore algorithm. Since it is precisely these occurrences that are of interest, the SeaWiFS global time series was re-binned and mapped without the coccolithophore mask applied to the level 3 data.

Maps of the dominant OWT for the high resolution $1 \mathrm{~km}$ images were generated for SeaWiFS, MODIS, MERIS and CZCS level 2 scenes. Daily maps of the dominant OWTs were computed from the fuzzy membership maps of the level 3 SeaWiFS global $9 \mathrm{~km}$ data set. Eight-day averages were computed from these daily maps and were used to derive a frequency distribution of the occurrence of open ocean coccolithophore blooms and a time series of coccolithophore bloom area for the mission history. The annual average bloom area was computed based on pixel area weighted by the frequency distribution sensu Brown and Yoder (1994).

\section{Results}

\subsection{Optical characterization of coccolithophore blooms}

The optimal number of clusters for the coccolithophore reflectance data set was chosen as eight based on the cluster validity functions (Fig. 3). These eight new reflectance means have been added to the existing set of eight types. Collectively, the new eight types form OWT 9 and represent different optical conditions exhibited by coccolithophore blooms as defined and selected for using the default CZCS/SeaWiFS algorithm (Brown \& Yoder, 1994). The mean and covariance matrix for each cluster were derived (Table 2), and these values were added to the existing OWT mean and covariance tables, which formed a new matrix of 16 reflectance means and covariance matrices.

There is a wide range in the spectral magnitudes of the reflectances for the coccolithophore data set, varying almost ten-fold for wavelengths between 410 and $555 \mathrm{~nm}$. The shapes were generally but not exclusively characterized by a peak at $490 \mathrm{~nm}$, which contrasts to sediment-laden waters as exhibited by OWTs 6-8 (Fig. 1) that have peaks at $555 \mathrm{~nm}$. The maximum peak at $490 \mathrm{~nm}$ was present in $96.6 \%$ of the pixels in the assembled coccolithophore data base. In Brown and Yoder (1994), mean normalized radiances were higher at $440 \mathrm{~nm}$ and $520 \mathrm{~nm}$ compared to $550 \mathrm{~nm}$ for coccolithophore blooms based on extracted data from CZCS imagery. Published values of in situ coccolithophore bloom reflectance spectra are rare. However, this type of peak at $490 \mathrm{~nm}$ was also seen in reflectance measurements from a coccolithophore bloom in the Bering Sea (Iida et al., 2002) and more recently in the Patagonian shelf (Garcia et al., 2011). In the former study, there were a few observations which exhibited the peak towards $555 \mathrm{~nm}$. In situ reflectance observations of a coccolithophore bloom by Smyth et al. (2002) southwest of England exhibit a peak that is shifted towards $555 \mathrm{~nm}$. This is the same data used in the present analysis. Gordon et al. (2009) modeled the scattering and backscattering of coccoliths, and showed that the shape of backscattering cross-section of model coccoliths decreased from 500 to $600 \mathrm{~nm}$, and also showed that retrieved backscattering coefficients of stations within a coccolithophore bloom showed maximum values in the blue and minimum values between 550 and $620 \mathrm{~nm}$. Such an optical property would enhance light reflectance at $500 \mathrm{~nm}$ relative to $555 \mathrm{~nm}$. The presence of detritus and colored dissolved organic matter which strongly absorb over the same range would dampen reflectance in the blue region relative to the green. Gordon et al. (2009) reported significant detrital absorption for the English Channel data set used by Smyth et al. (2002) and this could account for the reflectance peak shift towards $555 \mathrm{~nm}$. Thus, the overall reflectance shape for any coccolithophore bloom will be affected 


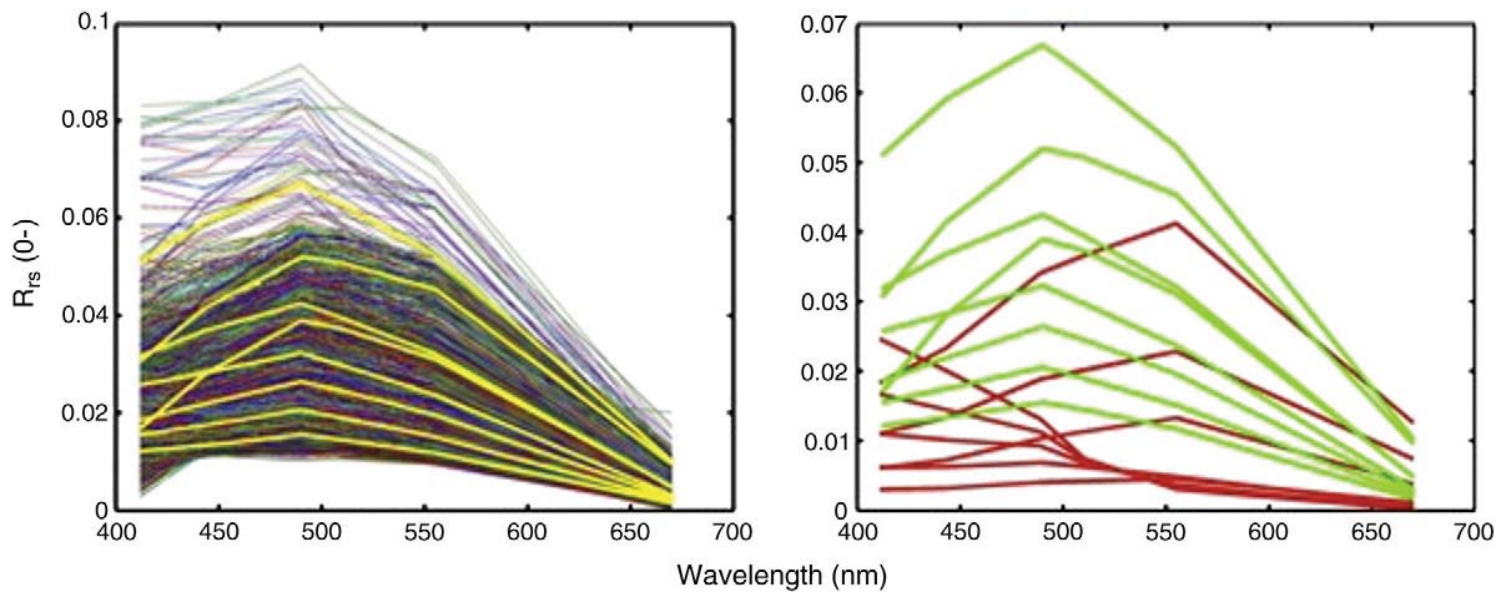

Fig. 3. Left: extracted $R_{r s}(0-)$ coccolithophore spectra from SeaWiFS images ( 2500 spectra shown) used for the clustering, along with cluster means (yellow lines). Right: combined coccolithophore cluster means (green) with the original eight OWT means (red) derived from the NOMAD data set.

by the background optical properties of the water in addition to the effects of the liths themselves.

The coccolithophore cluster means are generally much higher than the OWT means derived from NOMAD for all spectral bands, although there is a region of overlap between the sediment-related OWTs from NOMAD and the lower magnitude coccolithophore OWTs. There is a peak difference between coccolithophore blooms and sediment-dominated waters, with $490 \mathrm{~nm}$ as the peak for coccolithophore blooms and $555 \mathrm{~nm}$ as the peak for sediment-laden waters. This difference is a key distinction in discriminating between sediment waters and coccolithophore blooms, particularly in the overlap region. From a qualitative optical point of view, sedimentladen waters often look yellow or brownish-yellow, whereas coccolithophore blooms have a milky turquoise coloration.

\subsection{Application to ocean color imagery}

The fuzzy membership function was applied to ocean color satellite images, and membership maps were produced for each OWT with the new tables. Fig. 4 shows a SeaWiFS image for July 3, 2003 classified with the new OWT scheme. The bloom pattern as depicted by the dominant OWT map is highly correlated with high particulate inorganic carbon (PIC) features and high reflectance values at $555 \mathrm{~nm}$. The PIC model (Balch et al., 2005) is a function of the concentration of detached coccoliths. All images showed a similar result with a high correlation among the dominant OWT, PIC image and the standard coccolithophore mask. The range of mean PIC concentration from the model associated with the OWT patterns in all the SeaWiFS training images ranged from 0.0023 to $0.0096 \mathrm{~mol} / \mathrm{m}^{3}$. In all cases, the OWT method showed a greater bloom area compared to the

Table 2

Remote sensing reflectance $(0-)$ mean values for the eight clusters representing coccolithophore blooms.

\begin{tabular}{|c|c|c|c|c|c|c|}
\hline \multicolumn{7}{|c|}{ Remote sensing reflectance } \\
\hline Cluster & $R_{r s} 412$ & $R_{r s} 443$ & $R_{r s} 490$ & $R_{r s} 510$ & $R_{r s} 555$ & $R_{r s} 670$ \\
\hline 1 & 0.0122 & 0.0133 & 0.0155 & 0.0145 & 0.0117 & 0.0017 \\
\hline 2 & 0.0155 & 0.0175 & 0.0206 & 0.0190 & 0.0151 & 0.0021 \\
\hline 3 & 0.0186 & 0.0219 & 0.0265 & 0.0245 & 0.0196 & 0.0026 \\
\hline 4 & 0.0258 & 0.0282 & 0.0323 & 0.0297 & 0.0237 & 0.0032 \\
\hline 5 & 0.0169 & 0.0279 & 0.0389 & 0.0373 & 0.0311 & 0.0049 \\
\hline 6 & 0.0318 & 0.0368 & 0.0425 & 0.0395 & 0.0321 & 0.0048 \\
\hline 7 & 0.0307 & 0.0414 & 0.0520 & 0.0507 & 0.0454 & 0.0096 \\
\hline 8 & 0.0510 & 0.0591 & 0.0670 & 0.0627 & 0.0523 & 0.0102 \\
\hline
\end{tabular}

standard algorithm. Based on the 14 images, the coccolithophore bloom area was an average of 1.75 times greater using the OWT method compared to the standard bloom algorithm, and ranged from a low of 1.13 to a high of 2.75 times higher. The areal difference from the image shown in Fig. 4 was 6.2 times greater for the OWT method, and was left out of the average calculation.

A comparison of membership maps for a same-day image pair from SeaWiFS and MODIS Aqua is shown in Fig. 5. The implementation of the classification algorithm for each image was identical, except that the SeaWiFS classification used reflectances at 6 wavelengths - 412, 443, 490, 510, 555 and $670 \mathrm{~nm}$ - and the MODIS image used 5 wavelengths $-412,443,488,547$ and $665 \mathrm{~nm}$. The OWT scheme reproduces the bloom pattern in both the SeaWiFS and MODIS images and is not constrained by the wavelength choice. This aspect highlights the advantage of the OWT method's applicability across sensors with different band sets. There are reasons why the band limitation does not significantly manifest in the output map comparisons.

The OWT classifier is a function of the shape and magnitude of a reflectance spectrum, and both are important. One of the advantages of the OWT scheme is that the classifier can operate with fewer bands than it is capable. However, the impact of using fewer bands is minimized in this case because the reflectance magnitude is as strong a key feature as is the peak location for coccolithophore blooms. Since the classifier operates on the absolute values of spectral reflectance, the overall shape and magnitude of a pixel's reflectance spectra are compared against the OWT means. The shape and magnitude of a given pixel often retain enough of the reflectance characteristic to be assigned to the same OWT even with fewer wavelengths as input selection. This flexibility allows for the application to different sensors with different reflectance bands.

The OWT scheme provides continuity from the standard SeaWiFS algorithm to a generalized coccolithophore bloom algorithm that is applicable to a generalized set of wavelengths without requiring all SeaWiFS wavelengths to be present. The OWT method can thus be extended to CZCS and MERIS image scenes. Although they have different band sets, each image type can thus be processed with the same fundamental OWT structure by adjusting which set of bands in the OWT tables are used for the classification. Fig. 6 illustrates the classification of image scenes from CZCS and MERIS - each taken off the coast of Nova Scotia - that contained coccolithophore blooms. The dominant OWT 9 pattern is coherent with the high reflectance patches to the south of Nova Scotia in each image.

In some cases, part of the coccolithophore bloom is assigned to one or more of the high scattering OWTs (OWT 6-8) when computing 


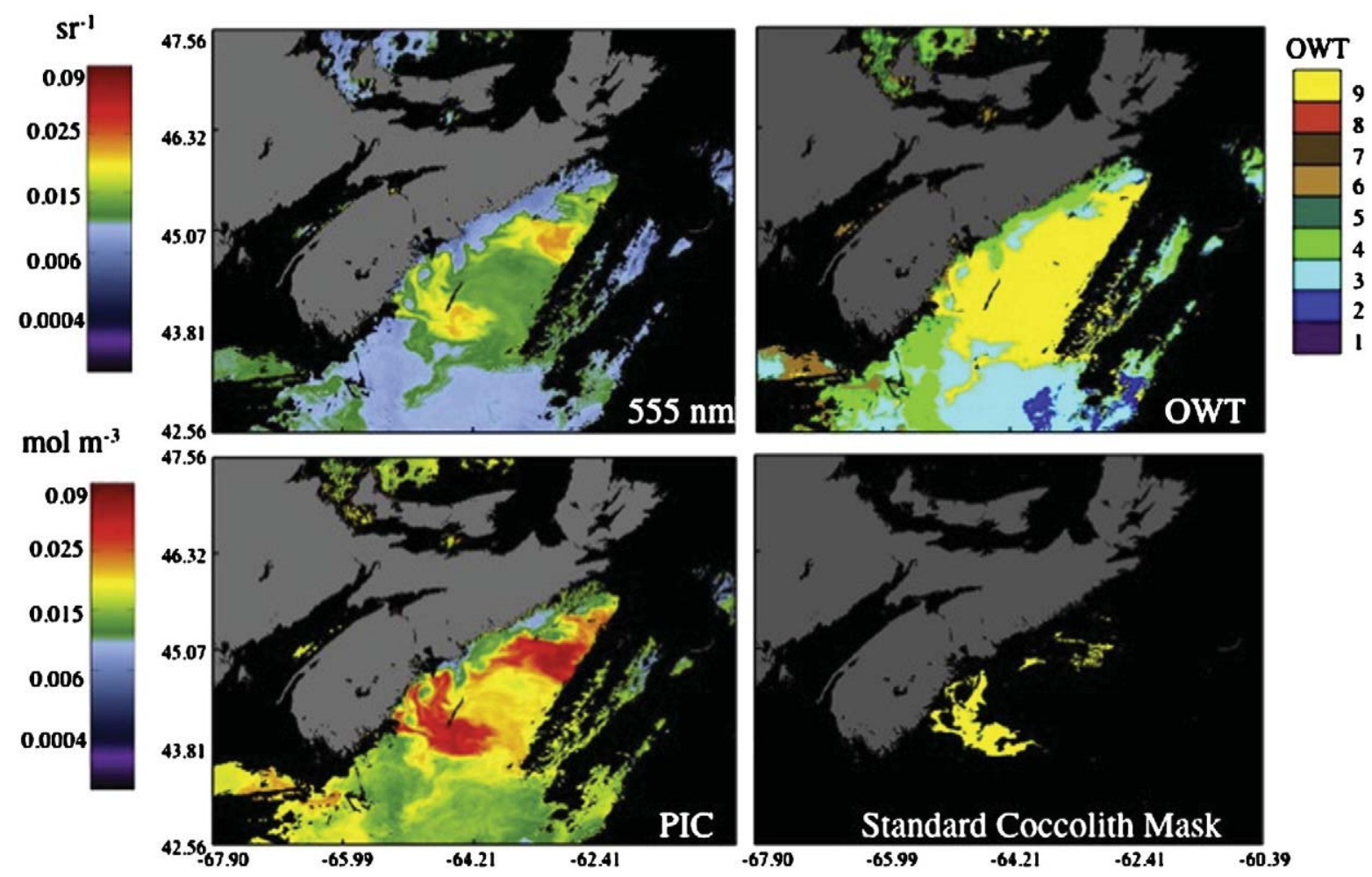

Fig. 4. SeaWiFS image with coccolithophore bloom southeast of Nova Scotia taken on July 3, 2003. Top left: remote sensing reflectance (above water) at 555 nm; bottom left: PIC image; top right: dominant OWT map; bottom right: coccolithophore flag mask.
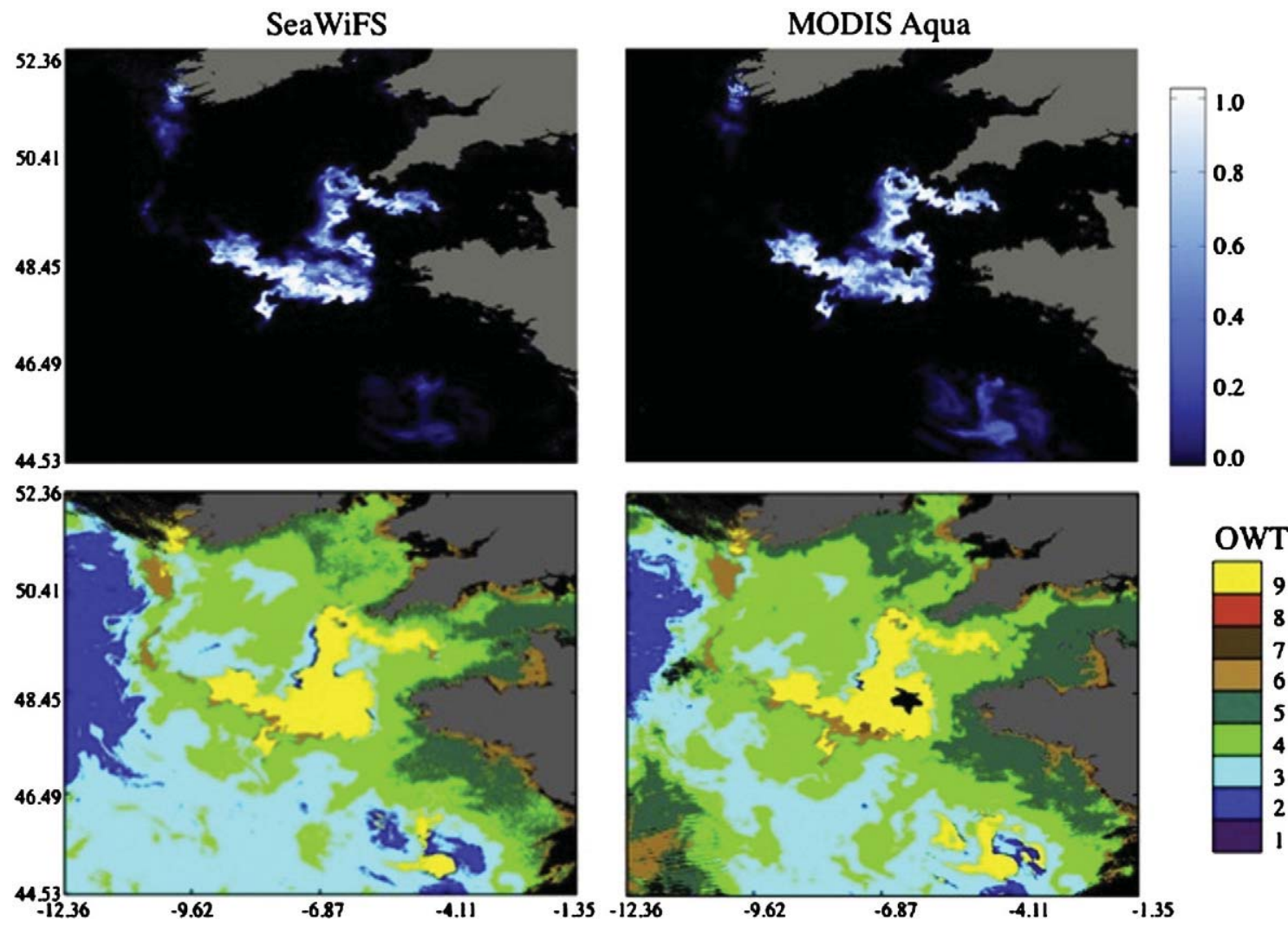

Fig. 5. Same-day SeaWiFS and MODIS Aqua image with coccolithophore bloom off the coast of France - June 15, 2004. Top left: SeaWiFS fuzzy membership map for coccolithophore class; bottom left: SeaWiFS dominant OWT map; top right: MODIS Aqua fuzzy membership map for coccolithophore class; bottom right: MODIS Aqua dominant OWT map (center hole in middle of bloom is a result of pixels masked out during level processing as being too bright). 

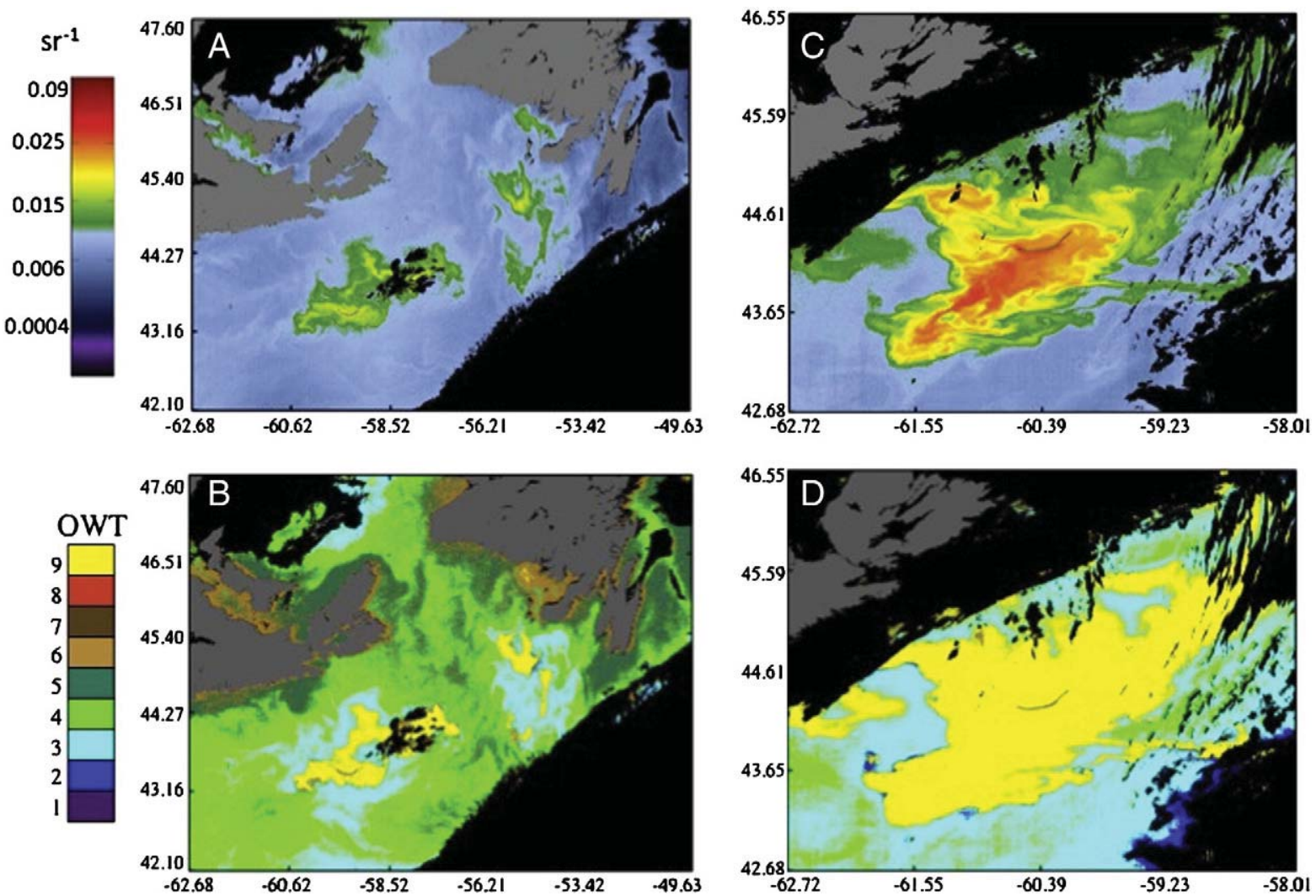

Fig. 6. Classification of CZCS and MERIS image scenes with coccolithophore blooms off the coast of Nova Scotia and surrounding Sable Island nearly 40 years apart. Top left (A): CZCS $R_{r s}(0+)$ at $555 \mathrm{~nm}$ for June 30,1981 ; bottom left (B):CZCS dominant OWT map for June 30, 1981; top right (C): MERIS $R_{r s}(0+)$ at $555 \mathrm{~nm}$ for July 5 , 2010 ; bottom right (D): MERIS dominant OWT map for July 5, 2010.

the dominant class. The mean reflectance spectra for these OWTs overlaps to varying degrees with some of the coccolithophore reflectance means. The class boundaries are governed by the means and the covariance matrices, and it is evident that some overlap exists. To examine the potential for mis-classification, the entire coccolithophore reflectance data set was run through the new OWT scheme. Of that data set, about $2 \%$ of the points were mis-classified into one of the sediment classes when judged on the basis of the dominant OWT. When the NOMAD data set was analyzed in the same way, there were no coccolithophore OWTs found.

\subsection{North Atlantic data set}

A summary of the results for the North Atlantic data set is shown in Table 3. In general, stations with high coccolithophore cell and lith counts were classified into OWT 9 and stations with low counts were classified into other OWTs. There were some differences between the satellite and in situ radiometry that resulted in different classifications for two of the stations. One station was classified as OWT 6 (sediment-like class) using in situ reflectances, while the same station was classified as OWT 9 using satellite reflectances. All stations except

Table 3

Data summary for the in situ data set from two separate coccolithophore blooms in the North Atlantic. Satellite match-ups that were not available (e.g., cloud effects) are designated as 'n/a'.

\begin{tabular}{|c|c|c|c|c|c|c|c|c|}
\hline \multicolumn{9}{|c|}{ In situ data set summary } \\
\hline Date & Lat & Lon & Cells/ml & Liths/ml & $\begin{array}{l}\text { OWT } \\
\text { (in situ } R_{r s} \text { ) }\end{array}$ & $\begin{array}{l}\text { OWT } \\
\left.\text { (Sat. } R_{r s}\right)\end{array}$ & $\begin{array}{l}\text { Cocco. flag } \\
\text { (in situ } R_{r s} \text { ) }\end{array}$ & $\begin{array}{l}\text { Cocco. flag } \\
\left.\text { (Sat. } R_{r s}\right)\end{array}$ \\
\hline $5 / 3 / 02$ & $47.414 \mathrm{~N}$ & $7.269 \mathrm{~W}$ & 381 & 15194 & 5 & $\mathrm{n} / \mathrm{a}$ & 0 & $\mathrm{n} / \mathrm{a}$ \\
\hline $5 / 4 / 02$ & $47.417 \mathrm{~N}$ & $7.266 \mathrm{~W}$ & 453 & 13284 & 4 & $\mathrm{n} / \mathrm{a}$ & 0 & $\mathrm{n} / \mathrm{a}$ \\
\hline $5 / 5 / 02$ & $47.741 \mathrm{~N}$ & $8.090 \mathrm{~W}$ & 99 & 9866 & 4 & $\mathrm{n} / \mathrm{a}$ & 0 & $\mathrm{n} / \mathrm{a}$ \\
\hline $5 / 5 / 02$ & $47.671 \mathrm{~N}$ & $8.197 \mathrm{~W}$ & 69 & 8534 & 3 & 4 & 0 & 0 \\
\hline $5 / 6 / 02$ & $47.677 \mathrm{~N}$ & $8.208 W$ & 99 & 9170 & 3 & $\mathrm{n} / \mathrm{a}$ & 0 & $\mathrm{n} / \mathrm{a}$ \\
\hline $5 / 7 / 02$ & $48.498 \mathrm{~N}$ & $8.904 W$ & 1838 & 43061 & 6 & 9 & 0 & 1 \\
\hline $5 / 8 / 02$ & $49.000 \mathrm{~N}$ & $9.996 \mathrm{~W}$ & 3445 & 78218 & 9 & $\mathrm{n} / \mathrm{a}$ & 0 & $\mathrm{n} / \mathrm{a}$ \\
\hline $5 / 9 / 02$ & $49.516 \mathrm{~N}$ & $10.858 \mathrm{~W}$ & 1571 & 91730 & 9 & 9 & 0 & 1 \\
\hline $5 / 9 / 02$ & $49.995 \mathrm{~N}$ & $10.502 \mathrm{~W}$ & 3901 & 110088 & 9 & 9 & 0 & 1 \\
\hline $5 / 9 / 02$ & $50.394 \mathrm{~N}$ & $10.595 \mathrm{~W}$ & 204 & 25909 & 3 & $\mathrm{n} / \mathrm{a}$ & 0 & $\mathrm{n} / \mathrm{a}$ \\
\hline 7/30/99 & $49.966 \mathrm{~N}$ & 4.167W & & 25614 & 9 & 9 & 1 & 1 \\
\hline 7/30/99 & $50.000 \mathrm{~N}$ & $4.165 \mathrm{~W}$ & & 275602 & 9 & 9 & 0 & 1 \\
\hline 7/30/99 & $50.104 \mathrm{~N}$ & 4.176W & & 268576 & 9 & 9 & 0 & 0 \\
\hline 7/30/99 & $50.230 \mathrm{~N}$ & $4.160 \mathrm{~W}$ & & 341948 & 9 & $\mathrm{n} / \mathrm{a}$ & 0 & $\mathrm{n} / \mathrm{a}$ \\
\hline
\end{tabular}


one were not designated as a 'coccolithophore bloom' by the SeaWiFS default bloom algorithm when based on in situ reflectances, while five stations were designated as 'blooms' based on satellite reflectances. These five stations were also all classified as OWT 9. The in situ reflectances with high coccolithophore cell counts generally had peaks at $555 \mathrm{~nm}$, whereas the satellite match-ups had reflectance peaks at lower wavelengths at either 490 or $510 \mathrm{~nm}$. These differences can account for the different outcomes of the schemes.

Differences between reflectance sources aside, the coccolithophore density threshold is into the thousands of cells $/ \mathrm{ml}$ and tens of thousands liths/ml for the OWT scheme and the standard SeaWiFS bloom detection algorithm according to this data set. These numbers are in line with the bloom criteria of Tyrrell and Merico (2004), which was set at a minimum of 1,000 cells $/ \mathrm{mL}$. The fewest number of cells detected by the OWT scheme with the North Atlantic data set was about 1,500 cells/mL based on the satellite radiances, but this may not be the absolute minimum detection threshold as there were no station data that with values between 500 and 1,500 cells $/ \mathrm{ml}$. The minimum lith concentration was about 43,000 liths/mL using satellite radiance and 78,000 liths $/ \mathrm{mL}$ using in situ radiances classified as OWT 9. The highest concentration of liths present that were not classified as blooms was about 26,000 cells/mL. For same reason, the lith threshold may be lower and lie somewhere between 26,000 and 43,000 liths/mL. Using conservative estimates, the potential cell density threshold is between 1,500 to 1,800 cells/mL and the lith threshold is between 43,000 and 78,000 liths/mL based on stations classified to OWT 9.

\subsection{Conditions that mimic coccolithophore blooms}

The optical characterization of coccolithophore blooms presented here was based on hand-selected images with known coccolithophore blooms, and the OWT classification method - like other algorithms assigns the bloom OWT to conditions and situations that are not always blooms. These include shallow areas with bottom reflection and waters with resuspended particles derived from sediments and/or empty diatom frustules (see Brown and Yoder (1994) and Tyrrell and Merico (2004)). These types of conditions have reflectance spectra in the overlap region between the sediment-type and coccolithophore OWTs, and resemble the above problem where coccolithophore blooms are assigned as sediment-type waters.

A type of classification problem that occurs near river mouths is illustrated using a SeaWiFS image in Fig. 7. The dominant OWT map shows a complex optical structure near the mouth of the Yangtze River, composed of varying sediment water types (OWTs 6-8), and a patch classified as the coccolithophore bloom OWT. This pattern is also replicated in the coccolithophore bloom mask, whereas the PIC image shows elevated concentrations throughout the turbid coastal waters. All three products are fooled by the turbid waters to varying degrees. In the OWT scheme, the transitional region between coccolithophore bloom and sediment has a gray zone. This gray zone can be seen when looking at the fuzzy memberships for OWTs 6-9 (Fig. 8). There is shared membership among these classes for the same pixels, especially between OWTs 7 and 9. In this particular case, there is almost equal membership to OWTs 7 and 9. The expression of the dominant OWT through the memberships obscures shared features, which are usually present when transitioning from one water type to another. Equal membership for an image feature to multiple classes indicates a transitional region (i.e., a fuzzy membership), and some degree of uncertainty as to which class it may belong. As this is a permissible result and even one of the advantages of the fuzzy scheme, it is nonetheless desirable to minimize this shared membership, and points out the need to further refine and define the boundaries between nearby classes in terms of their relations in
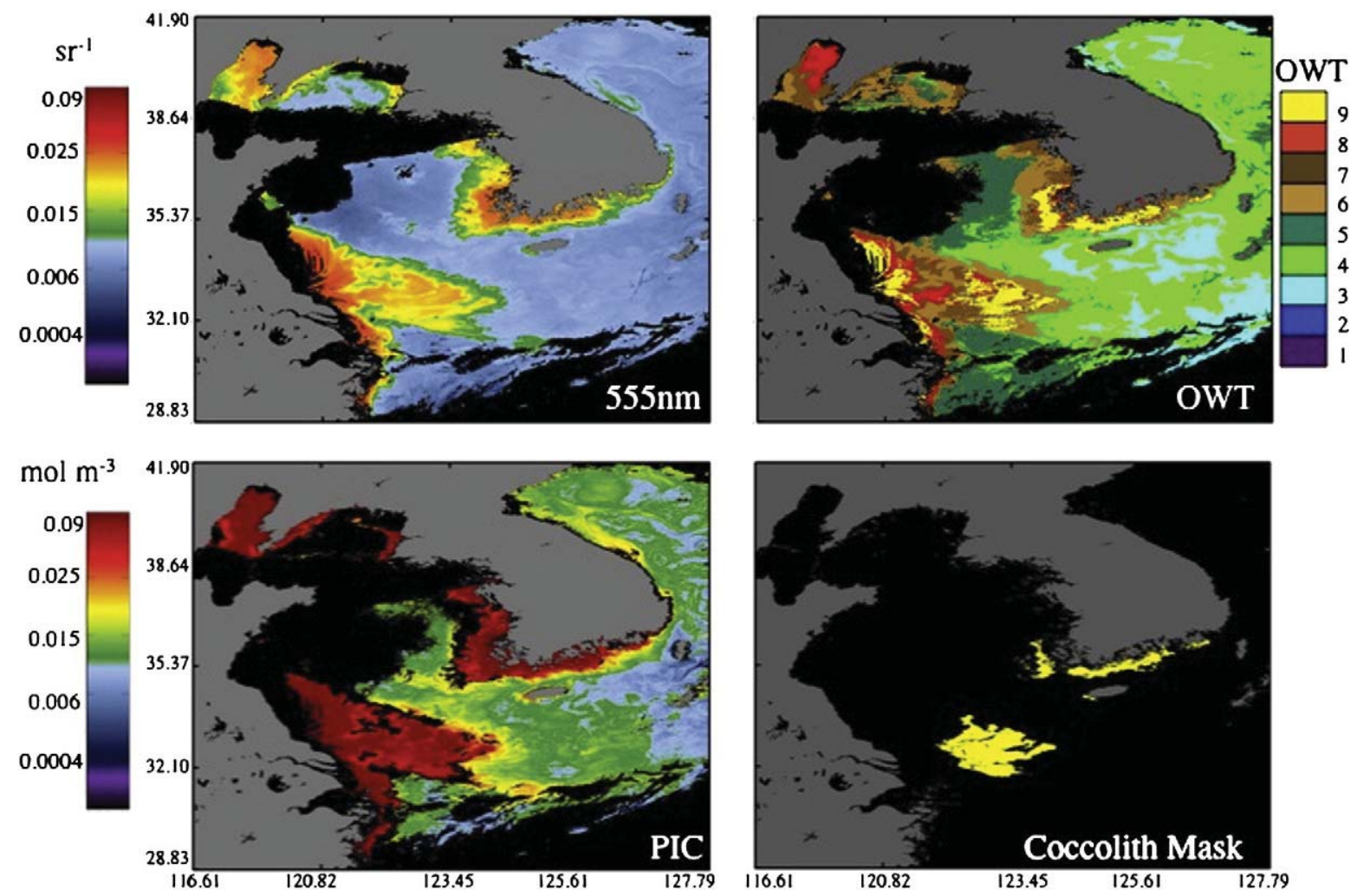

Fig. 7. SeaWiFS image over the Yellow Sea on May 10, 2001. Top left: $R_{r s}(0+)$ at $555 \mathrm{~nm}$; bottom left: PIC image; top right: dominant OWT map; bottom right: coccolithophore default mask. 

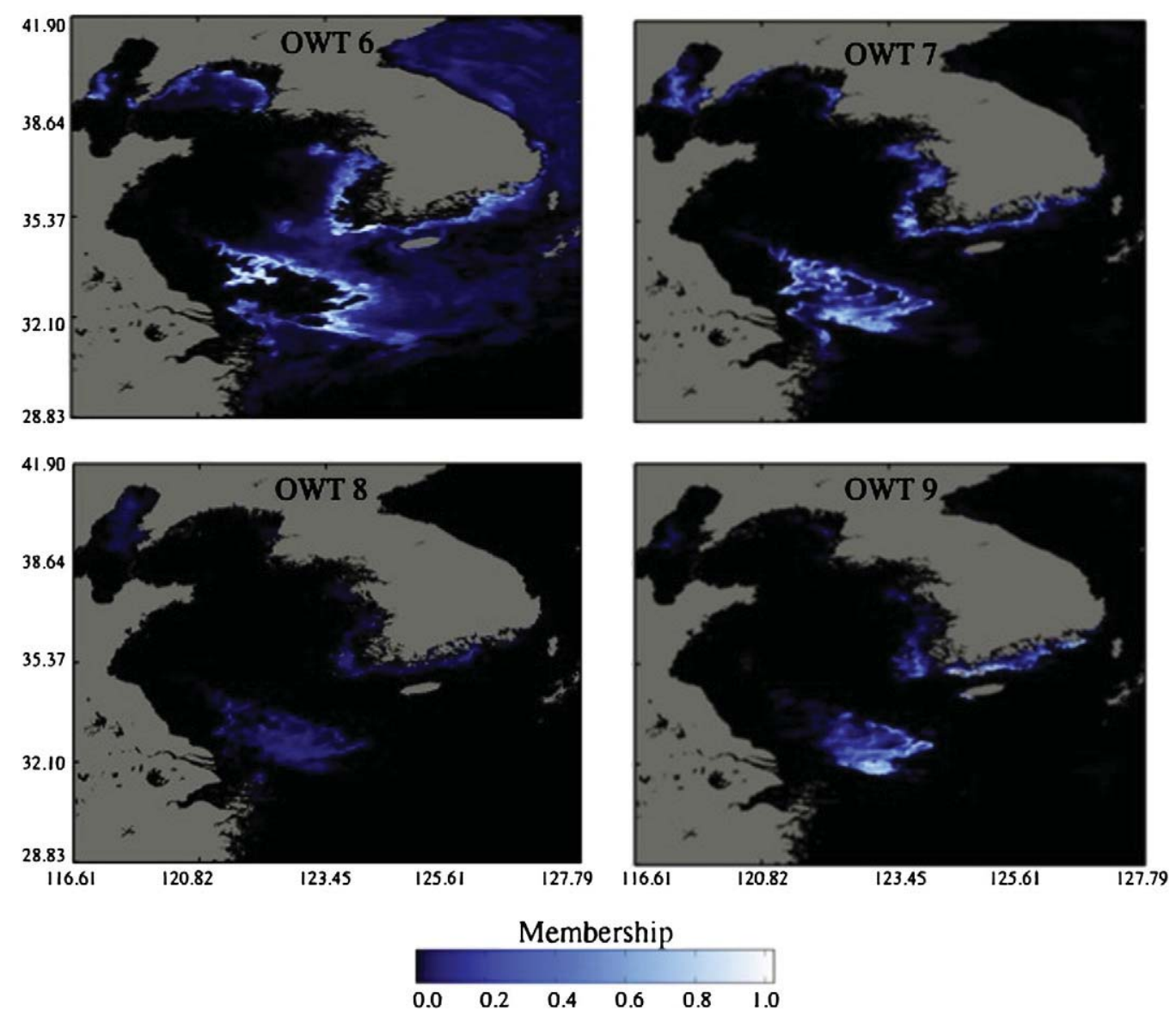

Fig. 8. Fuzzy membership maps for SeaWiFS image over the Yellow Sea on May 10, 2001. Top left: OWT 6; top right: OWT 7; bottom left: OWT 8; bottom right: OWT 9. Note overlapping memberships for OWT 7 and 9 in the offshore part Yangtze River plume.
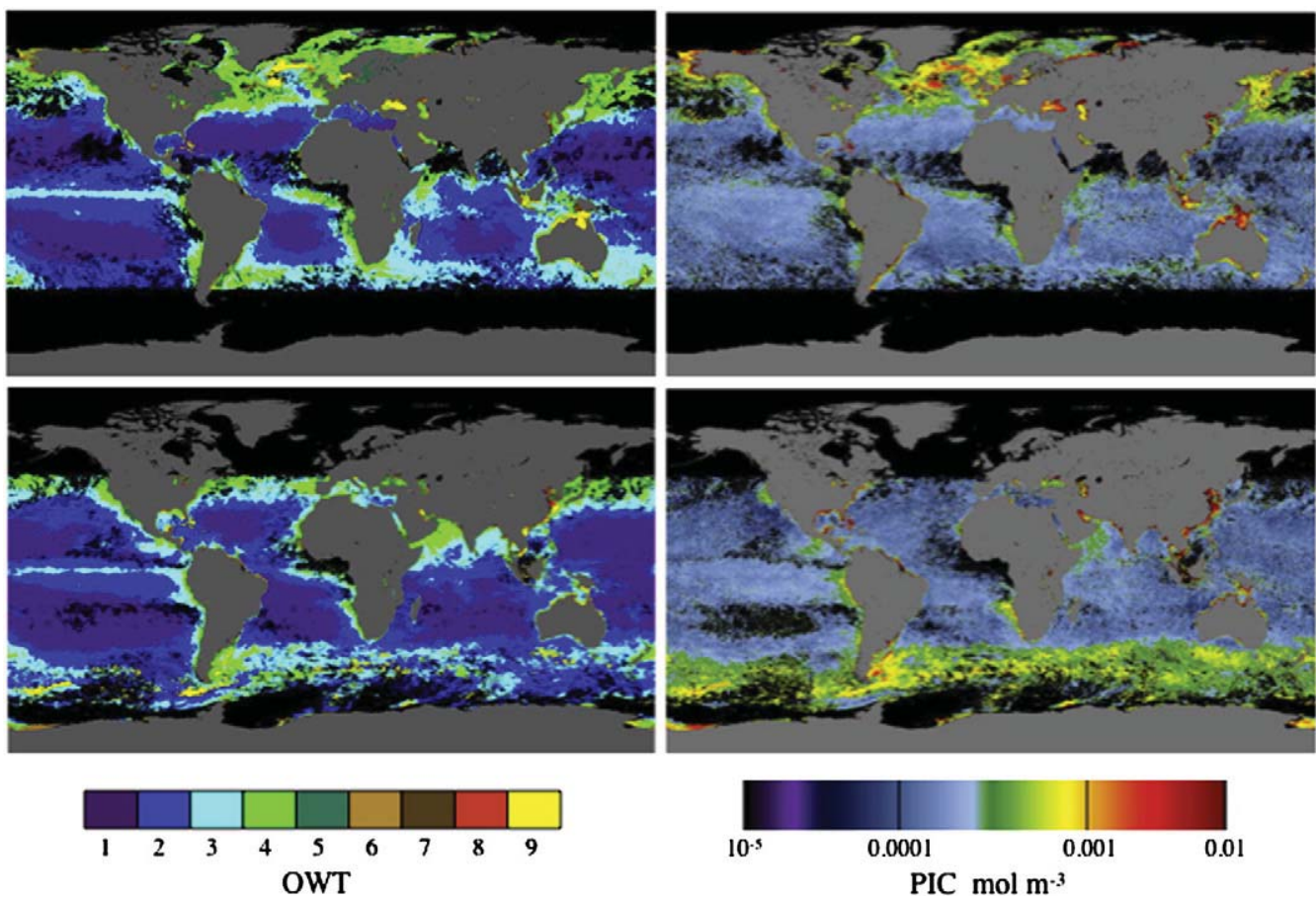

Fig. 9. Global monthly averages for SeaWiFS: top left: dominant OWT for June 2004; bottom left: dominant OWT for December 2004; top right: PIC for June 2004; bottom right: PIC for December 2004. 
reflectance space and/or statistical characterization of the membership function.

\subsection{Global analysis}

The dominant OWT monthly composites for June and December 2004 derived from SeaWiFS level 3 data are shown in Fig. 9. These months were chosen to highlight the northern and southern hemisphere summer patterns, respectively. The features in each image associated with OWT 9 are found in regions that are well-known for coccolithophore blooms (e.g., south of Iceland for the June image and along polar fronts in the Southern Ocean for the December image). The accompanying PIC maps show elevated PIC levels within these areas, and support the bloom patterns. From this global perspective, the OWT classification is capturing northern and southern hemisphere coccolithophore bloom events. This is interesting because there were no images from the Southern Ocean that were used as part of the training set, although three images were used from the Patagonian shelf. Part of the reason for this is that we did not find clear SeaWiFS images from the Southern Ocean with definitive blooms, although we did not conduct an exhaustive search. These issues will be covered in greater detail in the Discussion.

Maps of the global frequency of blooms derived from the dominant OWT 8-day averages for SeaWiFS are shown in Fig. 10. The 8-day averages of the dominant OWT maps were screened with the following criteria: water depth greater than $75 \mathrm{~m}$ to remove bottom reflection artifacts and minimum daylight exposure of $11 \mathrm{~h}$ to remove winter resuspension events. The maps reveal areas with persistently recurring coccolithophore blooms in both hemispheres. In the northern hemisphere, several well known regions within the North Atlantic are identified as high frequency bloom spots. These include the region south of Iceland, a coastal region from France extending around the British Isles, a patch to the southeast of Newfoundland, the coastal waters of Norway, the Barents Sea and the Black Sea. These areas exhibit extremely high frequency, meaning there is usually a bloom occurrence every year in these locations. Areas with a lesser frequency are seen in the North Pacific south of Alaska and the Aleutian Islands. The Bering Sea is seen as having some bloom occurrences within this time period, but shallow areas $(<75 \mathrm{~m})$ were screened which precludes much of this region from the analysis.

In the southern hemisphere, coherent bands of bloom persistence are found in the Southern Ocean. These regions are associated with specific frontal boundaries and have been previously noted to be conducive to bloom formation in the austral summer months (Findlay \& Giraudeau, 2000). The equator-most band that extends from the south of Australia and continues to the east of New Zealand towards South America is a bloom region associated with the Subtropical Front (STF) - the northern limit of Antarctic Circumpolar Current (ACC) - and has been observed with high concentrations (up to 200 cells $/ \mathrm{mL}$ ) of E. huxleyi (Findlay \& Giraudeau, 2000). Poleward of the STF is a region where several strong currents and fronts are formed within the ACC, which include the Subantarctic Front (SAF) and the Polar Front (PF). Both of these frontal regions have been observed with high cell concentrations of E. huxleyi - from 50 up to 500 cells/mL (Findlay \& Giraudeau, 2000; Gravalosa et al., 2008).

A high frequency region can be seen south of the STF, and extends along a broad band from New Zealand towards the southern tip of South America, and continues with sparser bloom patches eastward south of Africa and Australia. It is difficult to assign a specific front to the high frequency regions due to their close proximity and variable position (Belkin \& Gordon, 1996; Moore et al., 1999; Sokolov \& Rintoul, 2009). Each of these bands has been noted to be separate biogeographical zones with different assemblages (Cubillos et al., 2007; Findlay \& Giraudeau, 2000; McIntyre \& Be, 1967), although E. huxleyi was always found to be the dominant species (Eynaud et al., 1999; Findlay \& Giraudeau, 2000; Gravalosa et al., 2008; Holligan et al., 2010; Winter et al., 1999). However, it has been found that different forms of E. huxleyi have been identified based on morphological variations, and that these forms are associated with the different frontal systems (Cubillos et al., 2007; Findlay \& Giraudeau, 2000). Other high frequency regions in the southern hemisphere are seen on the Patagonian Shelf (Painter et al., 2010) and off the coast of Namibia (Siegel et al., 2007; Weeks et al., 2004), both of which are known to have coccolithophore blooms.

A time series of the areal extent of coccolithophore blooms (OWT 9) is shown in Fig. 11 as derived from eight-day averages of global dominant OWT maps for SeaWiFS. A $3 \times 3$ median filter was applied to the imagery to remove single-pixel artifacts resulting from cloud edges and other sources of contamination. A strong seasonal signal is expressed with peak areas occurring in summer months in both hemispheres, with inter-annual variability on the order of two-fold. The maximum areal extents of blooms occurred during austral summer months, reaching peak values between 3 and $8 \times 10^{6} \mathrm{~km}^{2}$. In contrast, northern hemisphere peaks generally reached somewhat smaller values, which were generally between 2 and $4 \times 10^{6} \mathrm{~km}^{2}$.

The annual average surface area of blooms was estimated to be $2.75 \times 10^{6} \mathrm{~km}^{2}$. This number is about twice as high as the value reported in Brown and Yoder (1994) which was estimated at $1.4 \times 10^{6} \mathrm{~km}^{2}$ from CZCS imagery. When examined by hemisphere, the annual bloom area average for the northern hemisphere is

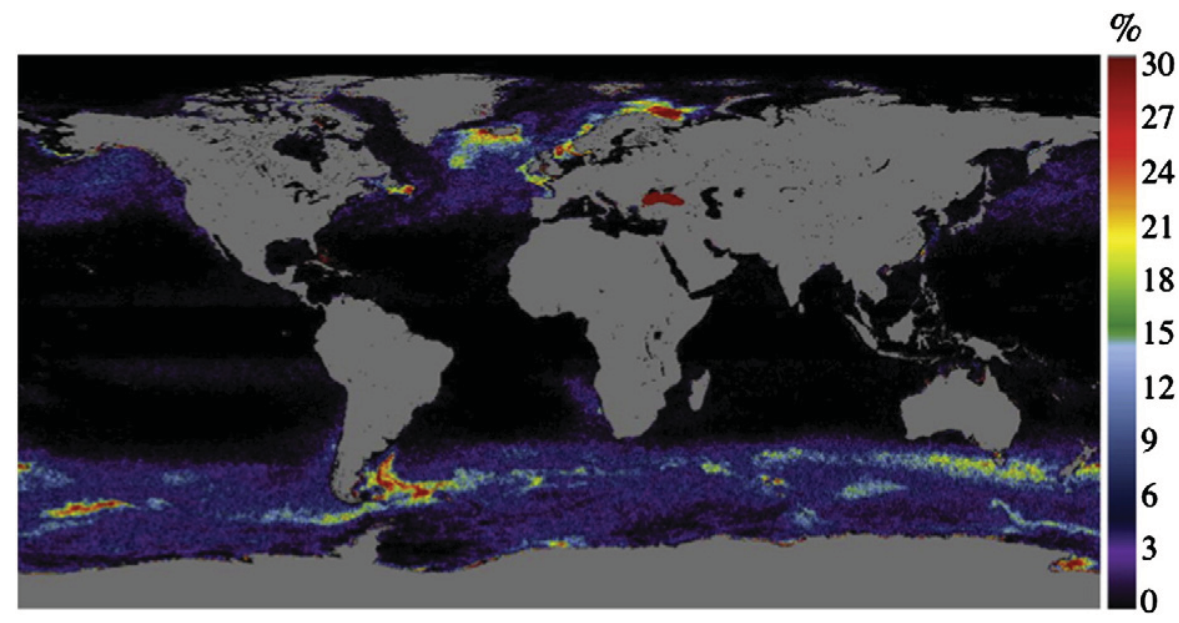

Fig. 10. Global frequency for coccolithophore blooms (OWT 9) derived from 8-day averages of the dominant OWT maps for SeaWiFS 1997-2010. Colorbar is the percentage that a bloom was present in the pixel. 


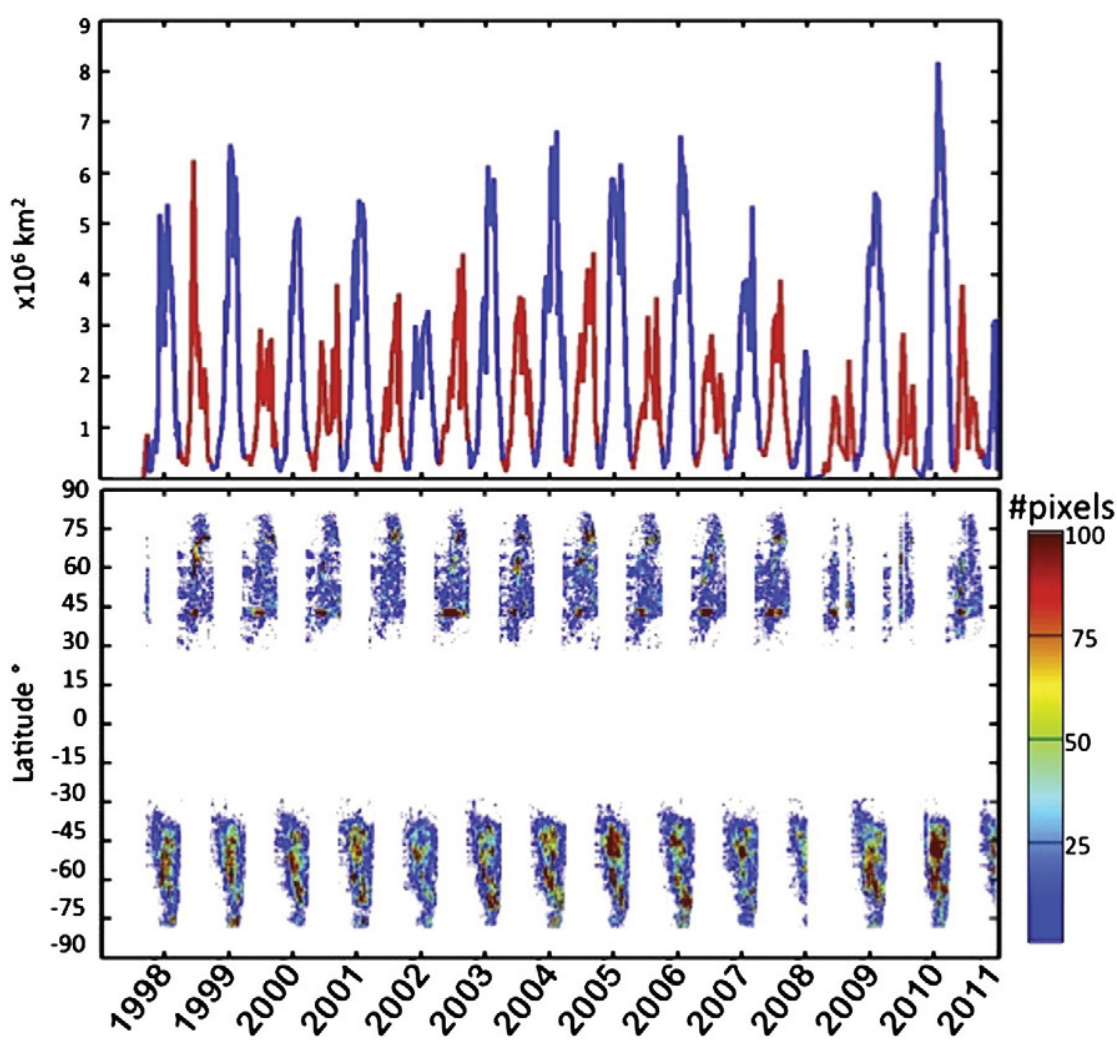

Fig. 11. Global area trend for coccolithophore blooms (OWT 9) derived from 8-day averages. Top: blue line - southern hemisphere summer; red line - northern hemisphere summer. Bottom: Time-latitude distributions of the zonal sum of pixels that were assigned as dominant OWT9 (coccolithophore bloom event). A poleward transition is seen in both hemispheres in every year between 45 and $75^{\circ}$.

$7.5 \times 10^{5} \mathrm{~km}^{2}$, whereas the southern hemisphere is more than two times greater with an annual average of $2.0 \times 10^{6} \mathrm{~km}^{2}$. The increase in area is a result of methodological differences - larger individual patch size computed with OWT method and the inclusion of Southern Ocean blooms - and other factors such as the improved global satellite coverage of SeaWiFS compared with CZCS.

\section{Discussion}

The conceptual notion of oceanic optical water types has precedence (Jerlov, 1976; Morel \& Prieur, 1977), and is rooted in the sources and types of optically active constituents present in the water column and their interaction with the light field. Since the prime measurement of ocean color satellites is the upwelled spectral light field, important ecological information can be gained from a classification scheme based on the ocean's optical signature. Within the OWT classification scheme based on the NOMAD data set, there was an obvious missing optical class that was specifically related to the bright reflectance signature associated with coccolithophore blooms. Although the scheme was originally based on in situ data, satellite observations have been incorporated into the OWT framework to account for optical classes not present in the NOMAD data, and coccolithophore blooms were specifically targeted here.

The detection of coccolithophore blooms apart from other phenomena related to bright water, such as re-suspended sediments or shallow water bottom reflection, remains problematic. Within the OWT scheme, we have previously defined several different water types that are associated with resuspended sediments, which have a remote sensing reflectance shape different than coccolithophore blooms. A key difference in our assembled data set between coccolithophore blooms and sediment-dominated waters is the peak wavelength for the reflected light, which is $555 \mathrm{~nm}$ for suspended sediments and $490 \mathrm{~nm}$ for coccolithophore blooms. This was generally true for most of the pixels that were extracted from satellite images in our analysis and in the limited number of reported values of field measurements for coccolithophore blooms (Garcia et al., 2011; Iida et al., 2002). Accounting for these other types of bright waters can help discriminate coccolithophore blooms apart from other phenomena. However, all 'bright' water conditions are not yet accounted for (e.g., shallow bottom reflection), and are outside the scope of this paper. The approach of integrating satellite observations with in situ observations in the OWT classification scheme may be applicable to these other conditions.

The main assumption in treating coccolithophore blooms as a single optical water type in the larger context of the OWT scheme is that the characterization of the reflectance spectra from satellite images is uniquely associated to this distinct bloom phenomenon. We assume that the reflectance data extracted from the collection of source images - although limited in number but fairly distributed geographically - is representative of coccolithophore blooms for the global oceans. There are areas omitted from this collection, notably the Southern Ocean and the Black Sea. We have chosen to treat the Black Sea separately as it has unique forcing at lower latitude than the oceanic coccolithophore bloom regions and is outside the scope of this current work. The coccolithophore radiometric data used were derived from SeaWiFS imagery, and based on the coccolithophore bloom mask of Brown and Yoder (1994) and Iglesias-Rodriguez et al. (2002). The criteria used for this algorithm - parallelepiped in design - naturally influenced and restricted the set of observations used for the coccolithophore bloom OWT. However, because of a different mathematical implementation for the OWT classification scheme, spectral reflectance observations not originally qualified as bloom pixels with the standard algorithm were classified as bloom pixels (e.g., Fig. 4). In every case we examined in the $1 \mathrm{~km}$ level 2 images in Table 1, the bloom patterns detected by the OWT method were larger than the bloom mask from which it was derived by an average factor of 1.75 . 
The main reason for the larger areas when using the OWT method lies in the conversion of the fuzzy membership maps to the dominant OWT map. Each OWT has a corresponding membership map which is completely independent from the maps of the other OWTs. That is, a membership value for a given observation is based on its relation to an OWT through the membership function, which is unique for each OWT. Conversely, the dominant OWT map is produced by the collective OWT membership ensemble, and each pixel is assigned to the OWT with the highest membership. It is possible to have low membership in an OWT, but still have that type be dominant. This occurs when a reflectance observation does not match or is a poor match to any of the OWTs in the collection. In other words, each pixel is assigned to the nearest OWT when generating the dominant OWT map. In waters surrounding and adjacent to coccolithophore blooms, pixels may be rejected by the standard algorithm for some criteria, but still be bright or have closer proximity to OWT 9 than other classes. This aspect of the scheme allowed for bright pixels to be considered OWT 9 pixels but were rejected by the standard algorithm, which was common in Southern Ocean imagery.

\subsection{Southern Ocean observations}

Our results show a greater areal extant of coccolithophore blooms in the Southern Ocean than has previously been shown (IglesiasRodriguez et al., 2002). Furthermore, the annual peak surface area of southern hemisphere blooms was generally 2-4 times higher than the northern hemisphere blooms (Fig. 11), and more than twice the annual average area. The patterns seen in the Southern Ocean coincide with regions of high PIC (Fig. 9), although Balch et al. (2005) did not consider these features as coccolithophore blooms. While elevated levels of light backscattering and reflectance have been observed in this region for the last decade from satellite, the source of the backscattering has remained debatable. Potential sources of observed elevated reflectances have been attributed to coccolithophores (Balch et al., 2005) and/or wind-induced bubbles (Zhang \& Lewis, 2002). However, recent bio-optical observations in the Southern Ocean during the Southern Ocean Gas Experiment confirm that the elevated levels of reflectance are at least partially attributable to coccolithophores (Balch et al., 2011). Furthermore, Balch et al. (2011) states that high reflectance waters in the Atlantic sector of the Southern Ocean were present in low wind speeds. Surface bubble populations are produced and sustained by wave action from high winds (Randolph et al., in review).

One possible reason for the discrepancy is that data on living coccolithophore cells in the Southern Ocean have been rare until recently (Findlay \& Giraudeau, 2000; Gravalosa et al., 2008; Holligan et al., 2010). Although first observations of E. huxleyi in the Southern Ocean were reported in 1936 (Findlay \& Giraudeau, 2000), few observations were taken and reported until the 1990's. These more recent studies reported the presence of living E. huxleyi cells in various parts of the Southern Ocean, and reaching concentrations as high as 500 cells/mL south of Australia in austral summer (Findlay \& Giraudeau, 2000). Cubillos et al. (2007) reported consistent cell concentrations of E. huxleyi of around 100 cells $/ \mathrm{mL}$, and up to 400 cells $/ \mathrm{mL}$ in a region south of Australia between 2001 and 2006 which was previously observed to be absent or rare absent of this species from campaigns in the 1980's and 1990's, including that of Findlay and Giraudeau (2000). Winter et al. (1999) also reported similar concentrations between Africa and Antarctica. More recently, Holligan et al. (2010) reported that high reflectance was positively correlated with PIC and coccolith abundance in the vicinity of the Drake Passage, and cell concentrations were potentially as high as $1000-2000$ cells $/ \mathrm{mL}$. Bloom definitions vary, but Tyrrell and Merico (2004) adopt a cell concentration minimum of 1,000 cells/mL to qualify as an $E$. huxleyi bloom. By this definition, the high PIC and bloom features as detected by the OWT method are under the threshold if the previous cell count research is representative of these features.

The Southern Ocean shows high levels of PIC from direct observation and satellite imagery, yet often shows little bloom evidence based on the standard coccolithophore detection algorithm. As an example, Fig. 12 shows a SeaWiFS image near the Drake Passage south of Argentina with a frontal feature that is associated with high levels of PIC, yet was not flagged as a coccolithophore bloom with the standard algorithm. Examination of the spectra from this feature show that the reflectance data do not conform to the existing parallelepiped criteria. The reason is that the extracted pixels share a peak at the $412 \mathrm{~nm}$ channel, which is higher than the threshold in the algorithm and were rejected. The reflectance levels at other channels are elevated, suggesting something in the water scattering back more light than a typical 'blue' water pixel. When the image is classified with to the OWT method, this same feature is assigned to OWT 9, although the memberships to this class were low to moderate but not high.

We examined other SeaWiFS images from the Southern Ocean with features attributed to OWT 9 with high PIC levels and no flags set from the standard coccolithophore bloom algorithm. Examination of the spectral reflectances from these features revealed similar patterns of elevated reflectance overall with a peak at the $412 \mathrm{~nm}$ channel. The question is, are these features coccolithophore blooms? If so, why do they look optically different compared to blooms from the northern hemisphere?

The optical appearance of coccolithophore blooms as identified with the OWT method in the Southern Ocean - particularly in the region of the ACC - appears to be optically different than coccolithophore blooms from the North Atlantic classified by the same method. There are differences to both shape and magnitude of typical reflectance spectra from these regions. As has been mentioned, bloom pixels from the northern hemisphere are characterized by high values throughout the visible spectrum with a peak at $490 \mathrm{~nm}$, whereas Southern Ocean 'bloom' pixels exhibit lower overall magnitudes - especially around $555 \mathrm{~nm}$ - with highest reflectance values lower in the blue region around $412 \mathrm{~nm}$, and do not display a peak at $490 \mathrm{~nm}$.

There are several possible reasons why the optical signature of coccolithophore blooms might look different between these regions assuming that it is not related to artifacts from atmospheric correction or bubbles. There is strong evidence that the numbers of coccolithophores that are typically reached in the Southern Ocean are fewer than those of the North Atlantic. Cell densities in various regions of the ACC have so far been reported to be up to 500 cells $/ \mathrm{mL}$, which contrasts to much higher values given in Tyrrell and Merico (2004) for various regions in the North Atlantic. The likely effect on reflectance would be lower overall backscattering from fewer detached coccoliths and thus lower reflectance, which is what we've seen in comparisons of Southern Ocean bloom reflectances (e.g., Fig. 12) to those found in the northern hemisphere from a small selection of satellite imagery. This could also be the reason why there is no distinct reflectance peak at $490 \mathrm{~nm}$, as a higher number of coccoliths might be needed to generate this peak. The higher reflectance at $412 \mathrm{~nm}$ in these Southern Ocean cases could also be linked to the amount of colored dissolved organic matter (CDOM) in the water, which strongly absorbs light in the blue region of the spectrum. From satellite analysis, the North Atlantic Ocean has a higher degree of CDOM absorption relative to other substances in the blue compared to the Southern Ocean (Siegel et al., 2002), and would tend to have absorption impact on reflectance at $412 \mathrm{~nm}$ in North Atlantic blooms. The lower amounts of CDOM in the Southern Ocean would tend to dampen the $412 \mathrm{~nm}$ reflectance signal to a lesser degree.

We speculate that it is likely the combination of lower overall coccolithophore cell counts and lower CDOM concentrations are the cause of the different spectral shapes and magnitudes between the oceans. Regardless of whether the minimum criteria of 1,000 cells $/ \mathrm{mL}$ for bloom status is reached within these Southern Ocean features, the evidence 

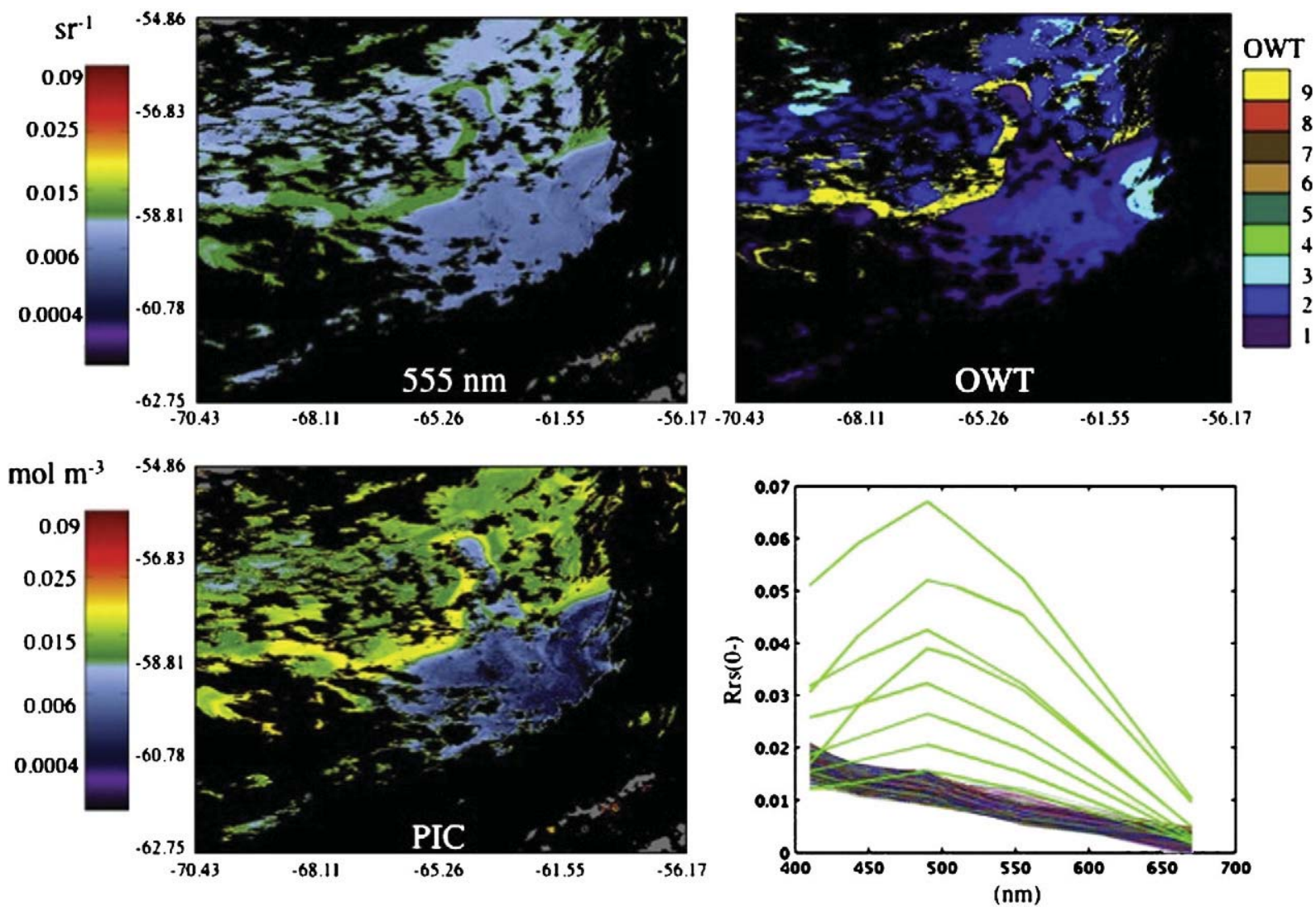

Fig. 12. SeaWiFS image from the Drake Passage on January 14,2003 . Top left: $R_{r s}(0+)$ at $555 \mathrm{~nm}$; bottom left: PIC image; top right: dominant OWT map; bottom right: $R_{r s}(0-)$ spectra from pixels classified as OWT 9 along with the OWT 9 reflectance means (green).

indicates that these high scattering features are attributed to coccolithophores present in sufficient numbers to alter the light field in such a way that they result in bright waters distinct from adjacent regions (Balch et al., 2011). It is likely that these particular conditions in the Southern Ocean will have to be accounted in future renditions of the OWT scheme, although whether they are associated with coccolithophore blooms, elevated PIC areas, or some other type of optical condition remains to be determined. In the case of a lower-level coccolithophore bloom condition, global coccolithophore bloom areas are currently underestimated and could potentially further increase the southern hemisphere bloom area relative to the northern hemisphere.

\subsection{Ecological significance}

One of the most striking phenomena that occur in the oceans is a coccolithophore bloom and the effect it has on the upwelled light field. This type of bloom is optically distinct from other phytoplankton blooms and is directly observable from satellites. It is unique among phytoplankton in this regard. Two species, E. huxleyi and Gephyrocapsa oceanica, are known to bloom (Blackburn \& Cresswell, 1993; Tyrrell \& Merico, 2004), although the majority of blooms are associated with E. huxleyi (Brown \& Yoder, 1994; Tyrrell \& Merico, 2004). Satellite observation of these blooms has afforded insights into their distributions and the ecological factors governing them (Iglesias-Rodriguez et al., 2002) that are not available for other species. The optical signature of coccolithophore blooms is largely a result of the detached coccoliths which are freely floating and not attached to living cells. The free floating coccoliths can result from coccolith overproduction, cell stress and cell death (Poulton et al., 2010). There is a positive correlation between the number of free floating coccoliths and living cells (Holligan et al., 2010), and thus an observed bloom pattern is indicative of living cells even though a large fraction of the signal itself is a result of dead cells and may be capturing the late bloom stage (Tyrrell \& Merico, 2004).

Coccolithophore blooms annually re-occur in specific regions (Fig. 10). In addition, the timing and sequencing of when these regions bloom are regulated by time-dependent processes as seen in the zonal sum of pixel counts of bloom events in a time-latitude plot based on 8-day composites of the dominant OWTs for SeaWiFS data (Fig. 11). In every year of observations between 1997 and 2010 , a poleward transition - sloping positive or negative for the northern and southern hemispheres, respectively - occurred for coccolithophore bloom events at regular intervals. Furthermore, the initiation of the blooms generally occurs around the 45 degree latitude and continues poleward to roughly $75^{\circ}$ in both hemispheres. The time/space domains of these blooms, although repeating on a regular cycle annually, exhibit some variability between years and over time. The similarity in the timing and progression of the OWT 9 distributions between the hemispheres is another compelling piece of evidence that supports the notion that the pixels identified as belonging to OWT 9 are coccolithophore blooms. We will further explore the Southern Ocean optical properties in the context of the OWT scheme in the near future.

The coccolithophore bloom observations produced here may serve as a vehicle for understanding the ecological factors behind this by connecting coccolithophore bloom patterns with the physical environment as has been previously shown by Iglesias-Rodriguez et al. (2002). It is widely believed that the overall frequency and extent of coccolithophore blooms will be impacted by changes in $\mathrm{pH}$ levels and the physical vertical structure of near surface of the oceans 
(Balch et al., 2008; Tozzi et al., 2004). These driving forces produce a response in coccolithophores which potentially negate each other. It is thought that the acidification of the oceans will result in a reduction of coccolithophores in the ocean (Balch et al., 2008), while an increase in stratification from changing weather patterns may result in an increase in coccolithophores from more favorable bloom conditions (Smyth et al., 2004; Tozzi et al., 2004).

Bloom conditions for coccolithophores define a specific niche which has been mapped on the Margalef Mandala (Balch et al., 2004). The common requirements for coccolithophore blooms in the northern and southern hemisphere are high light and high stratification (Balch et al., 2004). Genetic and morphological variations in the E. huxleyi species have been identified, and there are documented different types which may have different niche preferences as has been seen in the segregation of the types along different Southern Ocean fronts (Cubillos et al., 2007; Findlay \& Giraudeau, 2000). Thus, a universal niche for all types of E. huxleyi may not exist. Radiometric identification of these different types from space may not be feasible, but it's something we have not looked into.

\section{Summary}

The OWT method provides a common framework for the detection of coccolithophore blooms from ocean color satellites. The method is flexible for application to past and present ocean color satellites and is not significantly impacted by band differences and offers an advantage over the current coccolithophore bloom mask which has the $510 \mathrm{~nm}$ band requirement. The conservative threshold levels for the method were assessed at between 1,500 to 1,800 coccolithophore cells/mL and 43,000 to 78,000 liths/mL based on an in situ data set from the North Atlantic that sampled two different coccolithophore blooms. On average, the OWT method detected blooms that were 1.75 times larger than the default coccolithophore bloom mask. Our estimates for annual global surface area was $0.75 \times 10^{6} \mathrm{~km}^{2}$ and $2.00 \times 10^{6} \mathrm{~km}^{2}$ for the northern and southern hemispheres, respectively. These revised numbers indicate a larger contribution to coccolithophore blooms from the Southern Ocean than previously reported.

The bloom mask as derived from the OWT method is in itself an important ecological indicator of a unique phenomenon with global implications for biogeochemistry and climate change. We have observed annually recurring blooms in specific regions around the global oceans that appear to be part of a bloom sequence in both hemispheres, with the timing and locations of these blooms following regular patterns. The current method and time series analysis of global patterns of coccolithophore blooms will be important for continued and future monitoring of coccolithophore bloom activity and as an ecological indicator of oceanic response to climate forcing. Our work in this area is ongoing, and we will be assessing the optical properties of the Southern Ocean in high PIC areas that are currently showing low memberships to the OWTs. We believe these areas will add to southern hemisphere bloom area calculations, which are showing higher annual coccolithophore bloom area compared to the northern hemisphere. The Black Sea, which was not specifically covered in this work, will also be specifically analyzed and studied from the OWT perspective in upcoming research.

\section{Acknowledgments}

This work was supported by NASA grant NNX08AG80A. Thanks to Tim Smyth for providing the North Atlantic in situ data set that added significantly to the work. The authors thank the anonymous reviewers for their time in providing helpful comments and suggestions.

\section{References}

Balch, W. M., Drapeau, D. T., Bowler, B. C., Booth, E. S., Goes, J. I., Ashe, A., et al. (2004). A multi-year record of hydrographic and bio-optical properties in the Gulf of Maine: I. Spatial and temporal variability. Progress in Oceanography, 63, 57-98.

Balch, W., Drapeau, D., Bowler, B., Booth, E., Windecker, L., \& Ashe, A. (2008). Space time variability of carbon standing stocks and fixation rates in the Gulf of Maine, along the GNATS transect between Portland, ME, USA, and Yarmouth, Nova Scotia, Canada. Journal of Plankton Research, 30, 119-139.

Balch, W., Drapeau, D., Bowler, B., Lyczkowski, E., Booth, E., \& Alley, D. (2011). The contribution of coccolithophores to the optical and inorganic carbon budgets during the Southern Ocean Gas Experiment: New evidence in support of the "Great Calcite Belt" hypothesis. Journal of Geophysical Research, doi:10.1029/2011JC006941.

Balch, W., Gordon, H., Bowler, B., \& Booth, E. (2005). Calcium carbonate measurements in the surface global ocean based on Moderate-Resolution Imaging Spectroradiometer Data. Journal of Geophysical Research, doi:10.1029/2004JC002560.

Belkin, I., \& Gordon, A. (1996). Southern Ocean fronts from the Greenwich meridian to Tasmania. Journal of Geophysical Research, 101, 3675-3696.

Bezdek, J. C. (1981). Pattern recognition with fuzzy objective function algorithms. NY: Plenum.

Blackburn, S., \& Cresswell, G. (1993). A coccolithophorid bloom in Jervis Bay, Australia. Australian Journal of Marine E' Freshwater Research, 44, 39-49.

Brown, C., \& Yoder, J. (1994). Coccolithophorid blooms in the global ocean. Journal of Geophysical Research, 99, 7467-7482.

Cubillos, J., Wright, S., Nash, G., de Salas, M., Griffiths, B., Tilbrook, B., et al. (2007). Calcification morphotypes of the coccolithophorid Emiliana huxleyi in the Southern Ocean: Changes in 2001 to 2006 compared to historical data. Marine Ecology Progress Series, 348, 47-54.

Eynaud, F., Giraudeau, Pichon, J. -J., \& Pudsey, C. (1999). Sea-surface distributions of coccolithophores, diatoms, silicoflagellates and dinoflagellates in the South Atlantic Ocean during the late austral summer 1995. Deep-Sea Research I, 46, 451-482.

Findlay, C., \& Giraudeau, J. (2000). Extant calcareous nannoplankton in the Australian Sector of the Southern Ocean (austral summers 1994 and 1995). Marine Micropaleontology, 40, 417-439.

Garcia, C., Garcia, V., Dogliotti, A., Ferreira, A., Romero, S., Mannino, A., et al. (2011). Environmental conditions and bio-optical signature of a coccolithophore bloom in the Patagonian shelf. Journal of Geophysical Research, doi:10.1029/2010JC006595.

Gordon, H., Smyth, T., Balch, W., Boynton, G., \& Tarran, G. (2009). Light scattering by coccoliths detached from Emiliania huxleyi. Applied Optics, 48, 6059-6073.

Gravalosa, J., Flores, J. -A., Sierro, F., \& Gersonde, R. (2008). Sea surface distribution of coccolithophores in the eastern Pacific sector of the Southern Ocean (Bellingshausen and Amundsen Seas) during the late austral summer of 2001. Marine Micropaleontology, 69, 16-25.

Holligan, P., Charalampopoulou, A., \& Hutson, R. (2010). Seasonal distributions of the coccolithophore, Emiliania huxleyi, and of particulate inorganic carbon in surface waters of the Scotia Sea. Journal of Marine Systems, 82, 195-205.

Iglesias-Rodriguez, M. D., Brown, C. W., Doney, S. C., Kleypas, J., Kolber, D., Kolber, Z., et al. (2002). Representing key phytoplankton functional groups in ocean carbon cycle models: Coccolithophorids. Global Biogeochemical Cycles, 16, 1100.

Iida, T., Saitoh, S., Miyamura, T., Toratani, M., Fukushima, H., \& Shiga, N. (2002). Temporal and spatial variability of coccolithophore blooms in the eastern Bering Sea, 1998-2001. Progress in Oceanography, 55, 165-175.

Jain, A., Murty, M., \& Flynn, P. (1999). Data clustering: A review. ACM Computing Surveys, 31.

Jerlov, N. G. (1976). Marine optics. : Elsevier.

Lee, Z., Carder, K. L., \& Arnone, R. A. (2002). Deriving inherent optical properties from water color: A multiband quasi-analytical algorithm for optically deep waters. Applied Optics, 41, 5755-5772.

McIntyre, A., \& Be, A. (1967). Modern coccolithophoridae of the Atlantic Ocean - I. Placoliths and Cyrtoliths. Deep Sea Research, 14, 561-597.

Moore, J., Abbott, M., \& Richman, J. (1999). Location and dynamics of the Antarctic Polar Front from satellite sea surface temperature data. Journal of Geophysical Research, 104, 3059-3073.

Moore, T. S., Campbell, J. W., \& Dowell, M. D. (2009). A class-based approach for characterizing the uncertainty of the MODIS chlorophyll product. Remote Sensing of Environment, 113, 2424-2430.

Moore, T. S., Campbell, J. W., \& Feng, H. (2001). A fuzzy logic classification scheme for selecting and blending satellite ocean color algorithms. IEEE Transactions on Geoscience and Remote Sensing, 39, 1764-1776.

Morel, A., \& Prieur, L. (1977). Analysis of variations in ocean color. Limnology and Oceanography, 22, 709-722.

Paasche, E. (2002). A review of the coccolithophorid Emiliania Huxleyi (Prymnesiophyceae) with particular reference to growth, coccolith formation, and calcificationphotosynthesis interactions. Phycologia, 40, 503-529.

Painter, S., Poulton, A., Allen, J., Pidcock, R., \& Balch, W. (2010). The COPAS'08 expedition to the Patagonian Shelf: Physical and environmental conditions during the 2008 coccolithophore bloom. Continental Shelf Research, 30, 1907-1923.

Pal, N. R., \& Bezdek, J. C. (1995). On cluster validity for the fuzzy c-means model. IEEE Transactions on Fuzzy Systems, 3, 370-379.

Poulton, A., Charalampopoulou, A., Young, J., Tarran, G., Lucas, M., \& Quartly, G. (2010). Coccolithophore dynamics in non-bloom conditions during late summer in the central Iceland Basin (July-August 2007). Limnology and Oceanography, 55, 1601-1613.

Randolph, K., Dierssen, H., Twardowski, M., Lorenzen, A., \& Zappa, C. (in review). Optical measurements of bubble size distributions at 6-9 m depths generated by largescale breaking waves in the Southern Ocean. Journal of Geophysical Research. 
Rencher, A. C. (1995). Methods of multivariate statistics. : John Wiley and Sons, Ltd.

Shutler, J., Grant, M., Miller, P., Rushton, E., \& Anderson, K. (2010). Coccolithophore bloom detection in the north east Atlantic using SeaWiFS: Algorithm description, application and sensitivity analysis. Remote Sensing of Environment, 114, 1008-1016.

Siegel, D., Maritorena, S., \& Nelson, N. (2002). Global distribution and dynamics of colored dissolved and detrital organic materials. Journal of Geophysical Research, 107 (C12), doi:10.1029/2001JC000965.

Siegel, H., Ohde, T., Gerth, M., Lavik, G., \& Leipe, T. (2007). Identification of coccolithophore blooms in the SE Atlantic Ocean off Namibia by satellites and in-situ methods. Continental Shelf Research, 27, 258-274.

Smyth, T., Moore, G., Groom, S., Land, P., \& Tyrrell, T. (2002). Optical modeling and measurements of a coccolithophore bloom. Applied Optics, 41, 7679-7688.

Smyth, T., Tyrrell, T., \& Tarrant, B. (2004). Time series of coccolithophore activity in the Barents Sea, from twenty years of satellite imagery. Geophysical Research Letters, 31, doi:10.1029/2004GL019735.

Sokolov, S., \& Rintoul, S. (2009). Circumpolar structure and distribution of the Antarctic Circumpolar Current fronts: 2. Variability and relationship to sea surface height. Journal of Geophysical Research, 114, doi:10.1029/2008JC005248.
Tozzi, S., Schofield, O., \& Falkowski, P. G. (2004). Historical climate change and ocean turbulence as selective agents for two key phytoplankton functional groups. $\mathrm{Ma}$ rine Ecology Progress Series, 274, 123-132.

Tyrrell, T., \& Merico, A. (2004). Coccolithophores: From molecular processes to global impact, chapter Emiliania Huxleyi: Bloom observations and the conditions that induce them. : Springer-Verlag.

Tyrrell, T., \& Taylor, A. (1996). A modelling study of Emiliania huxleyi in the NE Atlantic. Journal of Marine Systems, 9, 83-112.

Weeks, S., Pitcher, G., \& Bernard, S. (2004). Satellite monitoring of the evolution of a coccolithophorid bloom in the southern Benguela upwelling system. Oceanography, 17, 83-89.

Werdell, P. J., Bailey, S. W. (2005). An improved in-situ bio-optical data set for ocean color algorithm development and satellite data product validation. Remote Sensing of Environment, 98, 122-140.

Winter, A., Elbrachter, M., \& Krause, G. (1999). Subtropical coccolithophores in the Weddell Sea. Deep-Sea Research I, 46, 439-449.

Zadeh, L. (1965). Fuzzy sets. Information Control, 8, 338-353.

Zhang, X., \& Lewis, M. (2002). The volume scattering function of natural bubble populations. Limnology and Oceanography, 45(5), 1273-1282. 